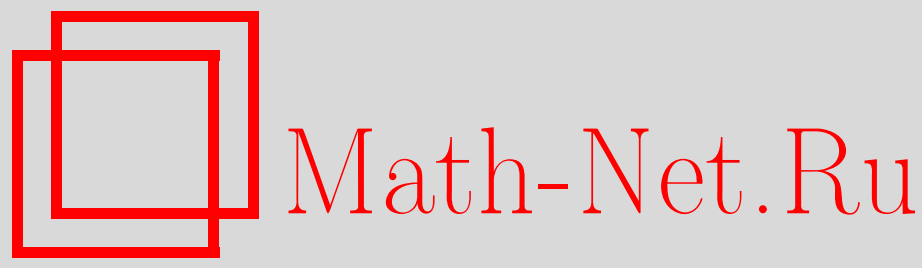

А. А. Карацуба, Комментарии к моим работам, написанные мной самим, Совр. пробл. матем., 2013, выпуск 17, 7-29

DOI: https://doi.org/10.4213/spm41

Использование Общероссийского математического портала Math-Net.Ru подразумевает, что вы прочитали и согласны с пользовательским соглашением http://www . mathnet.ru/rus/agreement

Параметры загрузки:

IP : 3.95 .254 .165

26 апреля 2023 г., 16:21:54

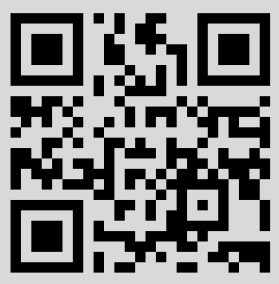




\title{
Комментарии к моим работам, написанные мной самим
}

\author{
А. А. Карацуба
}

Введение (от составителей ${ }^{1}$ ). В середине 80 -х годов Анатолий Алексеевич Карацуба сделал для себя сборник ксерокопий своих статей в хронологическом порядке в четырех томах и рукописные комментарии $^{2}$ к ним. Настоящая статья составлена из фрагментов этих (фактически дневниковых) записей: иногда авторский комментарий к той или иной работе приведен полностью, иногда частично (пояснения составителей даются в сносках, пропущенные строки обозначаются звездочками, пропущенные слова - точками).

В 1990-2000 гг. к некоторым комментариям А. А. Карацуба добавил короткие замечания по дальнейшему развитию темы (в настоящем тексте его комментариев эти более поздние замечания даются прописным шрифтом).

С 1954 г. по 1959 г. Анатолий Карацуба учился на механико-математическом факультете Московского государственного университета им. М. В. Ломоносова. Первым его руководителем был Андрей Николаевич Колмогоров, у которого он защитил курсовую работу 3-го курса под названием "О вариациях функций двух переменных" и курсовую работу 4-го курса "Эксперименты с автоматами". На основе "Экспериментов с автоматами" была написана первая статья А. А. Карацубы, с которой начинаются его комментарии.

А. А. Карацуба часто вспоминал свои студенческие годы, своих преподавателей и наставников профессоров МГУ. Вспоминал прогулки на лыжах, которые А.Н. Колмогоров устраивал для своих учеников, для чего хранил на своей даче 20 пар лыж и 20 пар лыжных ботинок, а также по 20 пар тапочек и чашек для последующего чаепития с учениками.

Запись А.А. Карацубы от 19 ноября 1985 г.: "Слушая Кэтлин Ферриер ${ }^{3}$ (Шуман на немецком языке), вспомнил Комаровку ${ }^{4}$, Павла Сергеевича ${ }^{5}$ и Андрея Николаевича ${ }^{6}$, их музыкальные концерты после лыж. Необыкновенная атмосфера, ни с чем не сравнимо (и никогда, по-видимому, не повторится). Другое время, другое отношение к науке. Редкий прагматизм и карьеризм".

Выбрав в качестве основного направления теорию чисел, в 1962 г. А. А. Карацуба защитил кандидатскую диссертацию "Рациональные тригонометрические суммы специального вида и их приложения" (руководитель - Николай Михайлович Коробов).

После защиты в 1966 г. докторской диссертации "Метод тригонометрических сумм и теоремы о среднем" А. А. Карацуба стал научным сотрудником Математического института им. В. А. Стеклова АН СССР (МИАН), которым в то время руководил Иван Матвеевич Виноградов. А. А. Карацуба всегда с восхищением относился к научным достижениям И. М. Виноградова. В [1] он писал о И. М. Виноградове: "Он решил проблему Гольдбаха, которая не поддавалась усилиям ученых в течение столетий, а метод тригонометрических сумм Виноградова коренным образом изменил лицо аналитической теории чисел и открыл новую эру в этой классической области математики". Там же: "Опираясь на небольшое количество математических понятий и фактов, он настолько глубоко проникает в сущность стоящих проблем, что это дает ему возможность и создать необходимый аппарат для решения, и решить проблему".

А. А. Карацуба всю жизнь вспоминал И. М. Виноградова и его высказывания по разным поводам. Из дневниковых записей А. А. Карацубы от 23 ноября 1983 г.: "Читаю-перечитываю (10-15 мин.) наши

${ }^{1}$ С. А. Гриценко, Е. А. Карацуба.

2 Заглавие, выбранное А. А. Карацубой для его комментариев, напоминает об одной из его любимых книг: Д. Дефо, "Жизнь и удивительные приключения Робинзона Крузо, моряка из Йорка, прожившего двадцать восемь лет в полном одиночестве на необитаемом острове у берегов Америки близ устьев реки Ориноко, куда он был выброшен кораблекрушением, во время которого весь экипаж корабля кроме него погиб; с изложением его неожиданного освобождения пиратами, написанные им самим".

${ }^{3}$ Kathleen Mary Ferrier.

${ }^{4}$ Деревня под Москвой, где находилась дача А. Н. Колмогорова.

${ }^{5}$ Павел Сергеевич Александров.

${ }^{6}$ Андрей Николаевич Колмогоров. 
книжки по альпинизму. Они грызут гору (Яник Сеньер ${ }^{7}$ и др.), упорно, трудно, холодно; я грызу математику, и чувства такие же. Вот где схожесть гор и математики. Сколько раз пытался бросить (реальный нуль), но что-то останавливает. Прав был И. М. ${ }^{8}$, говоря, что заниматься задачей надо до тех пор, пока теплится надежда (хоть чуть-чуть), что получится результат".

У Анатолия Алексеевича Карацубы была своя научная школа. Среди его аспирантов, защитивших кандидатские диссертации, были Г. Колесник ${ }^{9}$, С. Воронин ${ }^{10}$, Г. Архипов ${ }^{11}$, В. Чубариков ${ }^{12}$, М. Петечук $^{13}$, В. Плаксин ${ }^{14}$, 3. Рахмонов ${ }^{15}$, И. Джаббаров ${ }^{16}$, А. Лаврик ${ }^{17}$, С. Гриценко ${ }^{18}$, Г. Негматова $^{19}$, Д. Толев ${ }^{20}$, М. Королев ${ }^{21}$, М. Чанга ${ }^{22}$, И. Резвякова ${ }^{23}$. А. А. Карацуба любил всех своих учеников, радовался каждому новому полученному ими результату, гордился их успехами, переживал вместе с ними их неудачи и потери ${ }^{24}$.

В настоящей статье комментарии А. А. Карацубы касаются работ, выполненных до 1990 г. При этом в архиве не хватает комментариев к некоторым статьям третьего тома, а для четвертого тома найдена лишь одна страница комментариев (полный список научно-исследовательских работ А. А. Карацубы можно найти в [2]). Кроме того, в сборник, составленный А. А. Карацубой, не вошли его монографии (см. [3]-[11]). Не удалось найти полные имена некоторых упомянутых в тексте математиков. Приводятся только самые существенные ссылки. Однако даже в таком виде комментарии представляют собой интересный документ, который, возможно, окажется полезным математикам, работающим в области теории чисел и некоторых других областях чистой математики, а также в информатике ${ }^{25}$.

\footnotetext{
${ }^{7}$ Yannick Seigneur.

${ }^{8}$ И. М. Виноградов.

${ }^{9}$ Григорий Абрамович Колесник. Эмигрировал в США еще в советские годы, став "невозвращенцем", профессор Лос-Анжелесского университета, США.

${ }^{10}$ Сергей Михайлович Воронин. Профессор Московского педагогического государственного университета, ведущий научный сотрудник отдела теории чисел МИАН; умер в г. Москве в 1997 г.

${ }^{11}$ Геннадий Иванович Архипов. Профессор МГУ, ведущий научный сотрудник отдела теории чисел МИАН.

12 Владимир Николаевич Чубариков. Профессор МГУ, и.о. декана механико-математического факультета МГУ, заведующий кафедрой математических и компьютерных методов анализа.

${ }^{13}$ Михаил Михайлович Петечук. Научный сотрудник СКТБ "Квант" (Украина); умер в г. Ужгороде в 2001 г.

${ }^{14}$ Владимир Александрович Плаксин. Доцент кафедры теории вероятностей и анализа данных Петрозаводского государственного университета.

15 Зарулло Хусейнович Рахмонов. Профессор Таджикского государственного университета, заведующий кафедрой алгебры и теории чисел ТГНУ, директор Института математики АН Республики Таджикистан.

${ }^{16}$ Ильгар Шикар оглы Джаббаров. Доцент в Гянджинском государственном университете, Азербайджан.

${ }^{17}$ Алла Александровна Лаврик. Ассистент математического факультета Цюрихского технического университета (ЕTH Zürich), Швейцария; умерла в г. Цюрихе в 2003 г.

${ }^{18}$ Сергей Александрович Гриценко. Профессор Белгородского государственного университета, заведующий кафедрой алгебры, теории чисел и геометрии БГУ.

${ }^{19}$ Гавхар Дехкановна Негматова. Директор колледжа в г. Душанбе, Республика Таджикистан.

20 Дойчин Иванов (Иванович) Толев. Профессор кафедры математического анализа факультета математики и информатики Софийского университета, Болгария.

${ }^{21}$ Максим Александрович Королев. Старший научный сотрудник отдела алгебры и теории чисел МИАН.

22 Марис Евгеньевич Чанга. Доцент Московского государственного университета геодезии и картографии.

${ }^{23}$ Ирина Сергеевна Резвякова. Научный сотрудник отдела алгебры и теории чисел МИАН.

${ }^{24} \mathrm{~B}$ настоящей статье А. А. Карацубы не всем ученикам уделяется одинаковое внимание, что связано с объективными причинами. В то время, когда была написана основная часть комментариев, ученик А. А. Карацубы Г. И. Архипов устраивался на работу в МИАН на должность старшего научного сотрудника (что тогда было исключительно трудно для математика, который еще не являлся доктором наук) и защищал докторскую диссертацию. Поэтому работам Г. И. Архипова уделяется большое внимание, с самыми высокими оценками его вклада. Известно, что А. А. Карацуба очень высоко оценивал вклад и потенциалы и других своих учеников, некоторых из которых он называл лучшими математиками своего поколения.

${ }^{25}$ В то время как настоящая статья готовилась к печати, пришло известие о внезапной смерти Геннадия Ивановича Архипова.
} 
A.A. Kaparysoa

1.

1987r. Kouneriapure

KToman N1-N4

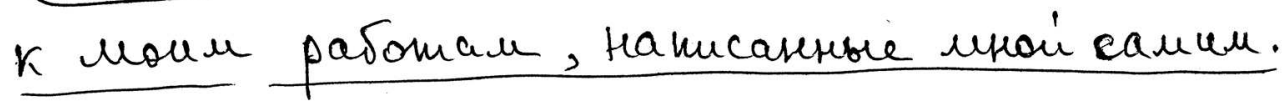

Toctapaner ombenumb ha boyoces: kak bog-

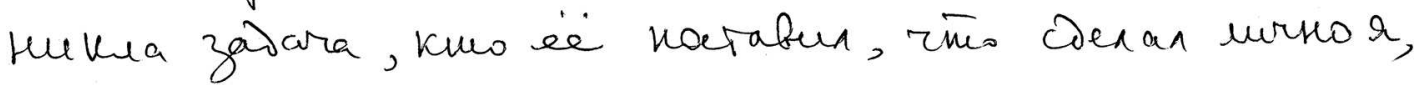

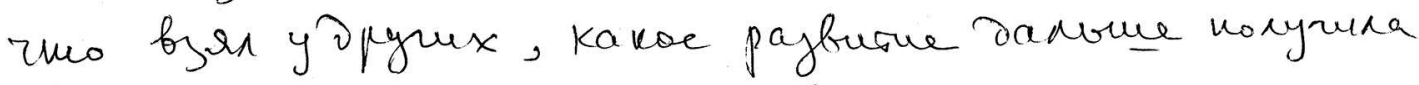

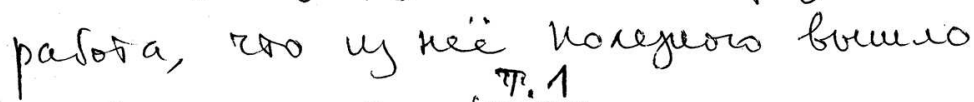

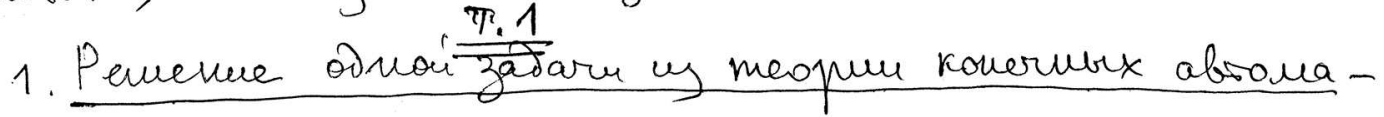
Tob, y MH , 1960, T. XV, b.3(93), c. 157-159

3adara noriabrena anequkanckum Maremaruksu-My-

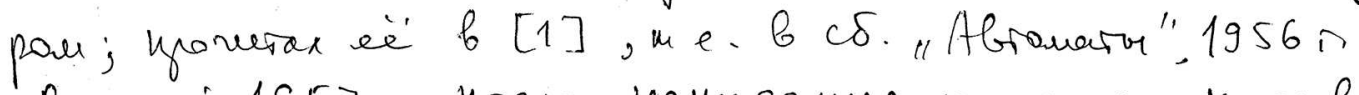
Becrosi 1957i., hocre reanucances u zareners kypcoboi pasoor ka 3-r kypee (kypcobar ranucana nod pyrobod-

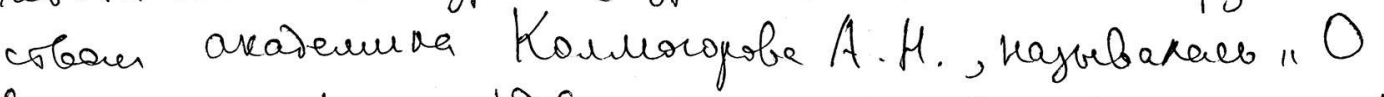

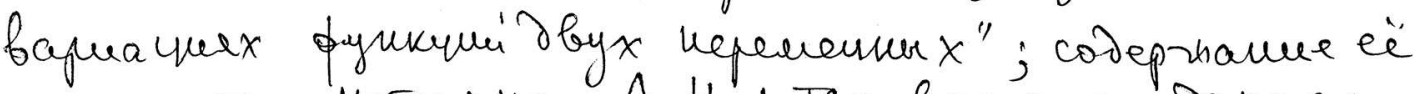

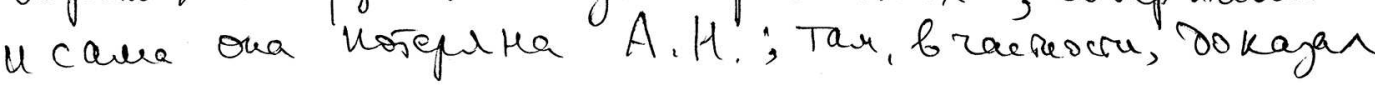
kakgro-so meopeny us meopen paguequocra no. A. H. Kalveropol, karoprin b aro bpene ormo akrabno

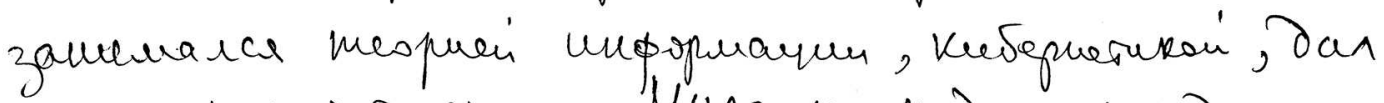

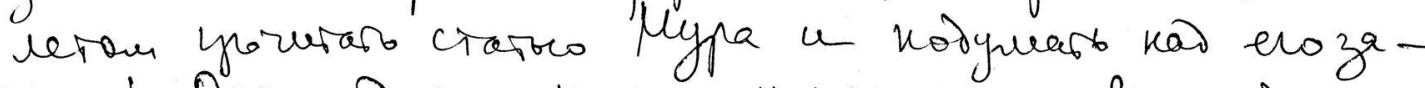
Darein. Orens dorro he less nothoro nocranobke zaiaru

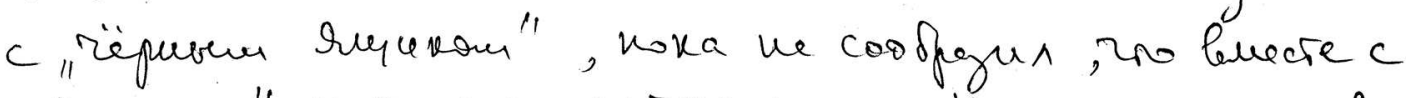
"erequrom" y zkchequment aropa euse ecro cxena abro.

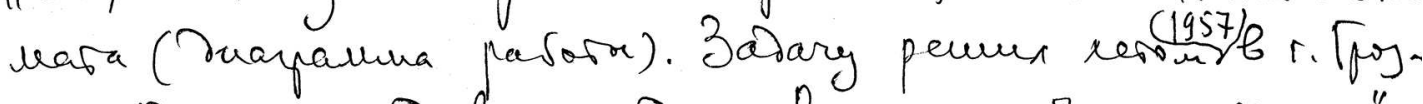

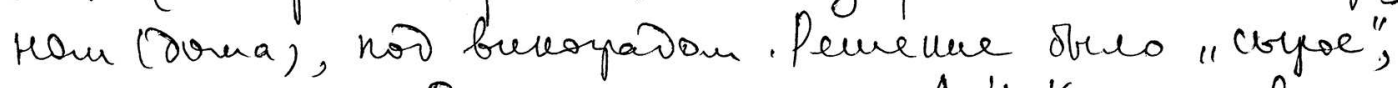

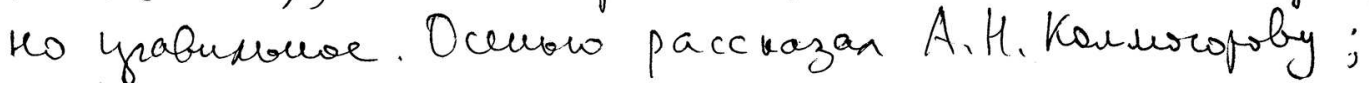


Постараюсь ответить на вопросы: как возникла задача, кто ее поставил, что сделал лично я, что взял у других, какое развитие дальше получила работа, что из нее полезного вышло.

\section{Toм 1}

1.1. “Решение одной задачи из теории конечных автоматов", Успехи математических наук, т. 15, № 3(93) (1960), с. 157-159. Задача поставлена американским математиком Муром ${ }^{26}$; прочитал ее в [12], т.е. в сборнике “Автоматы", 1956 г. Весной 1957 г., после написания и защиты курсовой работы на 3-м курсе (курсовая написана под руководством академика А.Н. Колмогорова, называлась "О вариациях функций двух переменных"; содержание ее и сама она потеряна А. H. ${ }^{27}$; там, в частности, доказал какую-то теорему из теории размерности по-другому) А. Н. Колмогоров, который в это время очень активно занимался теорией информации, кибернетикой, дал на лето прочитать статью Мура и подумать над его задачей. Очень долго не мог понять постановки задачи с "черным ящиком", пока не сообразил, что вместе с "ящиком" у экспериментатора еще есть схема автомата (диаграмма работы). Задачу решил летом 1957 г. в г. Грозном (дома ${ }^{28}$ ), под виноградом. Решение было "сырое", но правильное. Осенью рассказал А. Н. Колмогорову, в обсуждении принимал участие В.И. Арнольд ${ }^{29}$ (дело было в Комаровке). Все в этой работе придумал я (кроме той леммы Мура, на которую я ссылаюсь).

В 1961 г. Хиббард ${ }^{30}$ опубликовал в Америке работу, в которой по-существу переписал ${ }^{31}$ мою (с некоторыми обобщениями).

Весной 1958 г. эту работу я защитил как курсовую ...

Тогда же А.Н. Колмогоров сдал ее в УМН ${ }^{32}$; он очень помог придать ей тот законченный вид, который она сейчас имеет.

Наши 33 "ученые" Барздинь ${ }^{34}$ и Трахтенброт ${ }^{35}$ приписывают эти две мои теоремы Хиббарду $\left(\right.$ в своей книге $\left.{ }^{36}\right)$. В более ранней книге (забыл автора, нашего) теорема названа ${ }^{37}$ теоремой Мура-Карацубы. Сейчас наши университетские кибернетики ее так и называют.

Насколько мне известно, моя теорема является единственно точной (единственно точный нелинейный порядок оценки) в теории экспериментов с автоматами (т.е. не подлежащий уточнению результат). На эту тему много позже делал доклад в Берлине на Международном симпозиуме ${ }^{38}$; поставил там задачу (см. № 2.6); не знаю, решил ли ее кто-либо.

1.2. “Проблема Тэрри для системы сравнений”, Математический сборник, т. 55, № 2 (1961), с. 209-220. Задачу поставил профессор Н. М. Коробов в 1958 г. в качестве дипломной работы. Решил ее я в 1959 г. В это время Н. М. Коробов доказал “теорему о среднем

\footnotetext{
${ }^{26}$ Edward Forrest Moore.

27 А. Н. Колмогоров.

${ }^{28}$ А. А. Карацуба родился и вырос в г. Грозном.

${ }^{29}$ Владимир Игоревич Арнольд, однокурсник и коллега А. А. Карацубы.

${ }^{30}$ Thomas Nathaniel Hibbard.

${ }^{31}$ Имеется в виду "повторил"; на справедливость такого мнения указывает тот факт, что в работе Хиббарда фигурирует в точности автомат, построенный Карацубой, хотя разновидностей таких автоматов можно придумать очень много.

32 Журнал "Успехи математических наук".

${ }^{33} \mathrm{~B}$ момент этой записи упомянутые авторы, как и А. А. Карацуба, жили в СССР.

${ }^{34}$ Janis Barzdins.

${ }^{35}$ Борис Авраамович Трахтенброт.

${ }^{36}$ По-видимому, имеется в виду книга: Б. А. Трахтенброт, Я. М. Барздинь, Конечные автоматы. Поведение и синтез, М.: Наука, 1970.

37Эту теорему под названием теорема Мура-Карацубы можно найти, например, в книге: М. А. Айзерман, Л. А. Гусев, Л. И. Розоноэр, И. М. Смирнова, А.А. Таль, Логика. Автоматъ. Алгоритмы, М.: Физматгиз, 1963.

${ }^{38}$ Симпозиум по дискретной математике и приложениям в математической кибернетике 1974 г. в Берлине.
} 
для сравнений”, подобную теореме И. М. Виноградова ${ }^{39}$. Метод доказательства также Виноградовский. Мне надо было получить асимптотическую формулу для числа решений "гибридной" системы уравнений - сравнений. Я выучил статью Хуа Ло-кена ${ }^{40}$ (Acta Sci. Sinica, 1 $(1952))$, узнал, что такое точки первого и второго классов, как получается асимптотика, какую роль в этом играет теорема о среднем, и получил свою теорему. Работа в основном являлась учебной. После нее я мог решить любую аддитивную задачу типа проблемы Варинга-Тэрри ${ }^{41}$. Тогда же понял, что теорема Н. М. Коробова о среднем для этой системы и утверждение, тривиально следующее из теоремы о среднем И. М. Виноградова:

$$
N_{k}(P)=\sum_{\lambda_{r+1}, \ldots, \lambda_{n}} J\left(0, \ldots, 0, \lambda_{r+1} q, \ldots, \lambda_{n} q\right) \leqslant J \sum_{\lambda_{r+1}, \ldots, \lambda_{n}} 1
$$

для моих целей дают один результат.

Работа оказала большое положительное влияние на все мои последующие занятия теоремами о среднем и тригонометрическими суммами.

1.3. “Оценки тригонометрических сумм особого вида и их приложения”, Доклады АН СССР, т. 137, № 3 (1961), с. 513-514. Прочитал и понял статью И. М. Виноградова "Новая оценка $\zeta(1+i t)$ ", ИАН ${ }^{42}, \mathbf{2 2}(1958), 161-164^{43}$. Знал тематику А. Г. Постникова ${ }^{44}$ об $L$-рядах с $\chi\left(\bmod p^{n}\right), p \geqslant 3-$ постоянное. Понял, что Виноградовскую технику можно сюда перенести, что и сделал. Позднее это же делали Н. Г. Чудаков ${ }^{45}$, В.Н. Чубариков ${ }^{46}$ и $($ кажется) Г. Иванец ${ }^{47}$. Позднее техника, которую я здесь разрабатывал, получила применение в других моих работах. Таким образом, это одна из первых работ по теме, которая родила p-адический метод.

1.4. "Умножение многозначных чисел на автоматах", Доклады АН СССР, т. 145, № 2 (1962), с. 293-294 (совместно с Ю. Офманом ${ }^{48}$ ). Задачу о сложности умножения двух $n$-значных чисел поставил А.Н. Колмогоров. Впервые ее я услышал в 1956 г. В частности, на одном из заседаний Московского математического общества о ней говорил Колмогоров (1956 г.). Тогда же он говорил о том, что в “чешской системе счисления" 49 , т.е. в системе счисления остаточных классов, сложность умножения равняется $c n \log n$. А. Г. Витушкин $^{50}$ заметил, что если бы люди жили в этой системе счисления, то не было бы задачи Колмогорова; Колмогоров отметил, что система счисления возникла при измерениях, чтобы сравнивать величины, чего в “чешской системе счисления" сделать нельзя, так как по записи двух чисел в ней нельзя узнать, какое из них больше.

А.Н. Колмогоров думал, что нижняя оценка сложности есть $O\left(n^{2}\right)$, т.е. “человечество за много тысячелетий выбрало (создало) оптимальный способ умножения, которым мы пользуемся и сейчас".

Эта задача всегда меня привлекала. Даже летом 1956 г. в г. Грозном я говорил о ней своему школьному учителю Н. А. Кузьменко ${ }^{51}$. Осенью 1960 г. А. Н. Колмогоров организовал

\footnotetext{
${ }^{39} \mathrm{O}$ теореме Виноградова "о среднем" см., например, [7; с. 90], см. также [11; с. 88].

${ }^{40}$ Hua Lo-keng или Hua Luogeng. См. [13].

${ }^{41}$ Gaston Tarry. О проблеме Тэрри см., например, [7; с. 26], см. также [11; с. 20].

${ }^{42}$ Известия АН СССР. Серия математическая.

${ }^{43}$ См. [14].

${ }^{44}$ Алексей Георгиевич Постников.

${ }^{45}$ Николай Григорьевич Чудаков.

${ }^{46}$ Владимир Николаевич Чубариков, ученик А. А. Карацубы.

${ }^{47}$ Henryk Iwaniec.

${ }^{48}$ Юрий Павлович Офман.

49“Чешская система счисления", аббревиатура CSS, была построена чешскими математиками Антонином Свободой и Мирославом Валахом в [15].

${ }^{50}$ Анатолий Георгиевич Витушкин.

${ }^{51}$ Николай Акимович Кузьменко. Учитель математики и руководитель математического кружка в мужской средней школе № 6 г. Грозного.
} 
семинар по кибернетике, на первом заседании которого повторил эту задачу (как и другие). Неделю я упорно думал над ней, стараясь получить оценку снизу $O\left(n^{2}\right)$. Разбил число на два блока и фантазировал. Вдруг увидел, что вместо нижней оценки $O\left(n^{2}\right)$ получается верхняя вида $O\left(n^{\log _{2} 3}\right)$. Рассказал Н. М. Коробову (в МИАНе). Он как-то равнодушно отнесся к этому. После очередного заседания семинара рассказал А. Н. Колмогорову (на квартире у него). Он сначала не поверил, попросил тут же посмотреть В. М. Тихомирова ${ }^{52}$. Тихомиров подтвердил, что все правильно. А.Н. Колмогоров, по-видимому, очень огорчился. На очередном заседании семинара рассказал о моей работе, и на этом семинар прекратил работу (так расстроился Колмогоров). Затем он ездил по свету..., в Англии рассказал этот результат Эрдешу ${ }^{53}$, pacсказывал многим ${ }^{54}$ и, наконец, не сообщив мне, опубликовал (и, наверное, сам написал) эту заметку. Потом в СССР приезжал Штрассен ${ }^{55} \ldots$ и сделал ${ }^{56}$ на этой моей идее ${ }^{57} .$. умножение матриц ${ }^{58}$. Чуть раньше мой результат уточнил А. Тоом ${ }^{59}$ (ученик О.Б. Лупанова ${ }^{60}$, а затем - И. И. Пятецкого $\left.{ }^{61}\right)$. На Западе эта тематика получила широкое развитие - быстрые вычисления (например, быстрое преобразование Фурье ${ }^{62}$ в идейном отношении близко к моей работе). Есть монография: Д. Кнут, Искусство программирования, т. 2, где (тенденциозно) описана история возникновения быстрых вычислений 63 .

Появился ${ }^{64}$ т. 3 Избранных трудов А. Н. Колмогорова, 1987 г., М.: Наука; на с. 199 помещен его доклад на Международном математическом конгрессе в Стокгольме (1962 г.), в котором: “Обычный школьный рецепт умножения дает лишь

$$
m(s) \preccurlyeq s^{2},
$$

а оценки Офмана и Карацубы таковы:

$$
s \preccurlyeq m(s) \preccurlyeq s^{\log _{2} 3 . "}
$$

Таким образом, оценка Офмана: $m(s) \succcurlyeq s$, т.е. тривиальность. Бред какой-то.

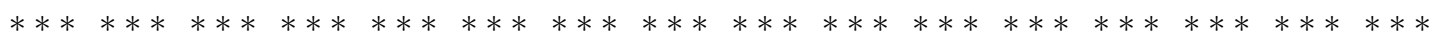

В 1967 г. (или около того) я сделал

$$
M(n)=O\left(n \log n \log \log n \log \log \log n \ldots(\underbrace{\log \log \ldots \log n}_{r})^{2}\right),
$$

$r \geqslant 2$ любое; А. Н. ${ }^{65}$ представил в ДАН ${ }^{66}$ и спросил, можно ли отправить работу за границу (рукопись) своим друзьям-коллегам. Я согласился. Затем я обнаружил неточность, которая

\footnotetext{
${ }^{52}$ Владимир Михайлович Тихомиров.

${ }^{53}$ Pál Erdös.

${ }^{54}$ Открытый А.А. Карацубой метод умножения явился первым быстрым методом, и само его открытие было удивительным сюрпризом для А. Н. Колмогорова и других специалистов в этой области.

${ }^{55}$ Volker Strassen.

${ }^{56}$ В 1969 г.; см. [16].

${ }^{57} \mathrm{~B}$ той или иной мере все существующие быстрые алгоритмы используют идею А. А. Карацубы, по крайней мере в виде используемого в них быстрого умножения.

58 Обобщение идеи А. А. Карацубы с умножения чисел на умножение матриц технически нетривиально.

${ }^{59}$ Андрей Леонович Тоом. См. статью: А.Л. Тоом, “О сложности схемы из функциональных элементов, реализующей умножение целых чисел”, Докл. АH CCCP, 150:2 (1963), 496-498.

60 Олег Борисович Лупанов.

${ }^{61}$ Илья Иосифович Пятецкий-Шапиро.

${ }^{62}$ Первый алгоритм быстрого преобразования Фурье появился в 1965 г.

${ }^{63}$ Cм. [17].

${ }^{64}$ CM. [18].

65 А. Н. Колмогоров.

66 Доклады Академии наук CCCP; для публикации статьи в этом журнале требуется представление статьи одним из академиков по специальности.
} 
достаточно просто исправлялась, забыл на индексы суммирования знак $\neq$ поставить, огорчился и забрал рукопись с представлением А.Н. Вскоре появилась ${ }^{67}$ работа... с этим же алгоритмом, а в 1971 - ... новая работа ${ }^{68}$ (с FFT $\left.^{69}\right)$.

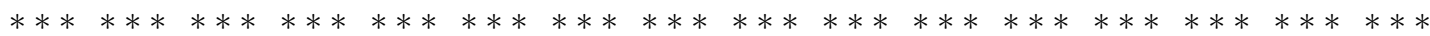

1.5. “Аналог проблемы Варинга”, Вестник МГУ, № 1 (1962), с. 38-46. Был второй год аспирантуры. Н. М. Коробов спросил как-то, чем я хотел бы заниматься: продолжать тему А. Г. Постникова ( $L$-ряды и т.п., что я уже сделал) или заняться конечными рядами Фурье и их приложениями к вычислению интегралов. Я выбрал первое. Мне нужны были задачи (темы) для кандидатской работы. Стал думать. Придумал эту задачу. Мысль такая: чем короче прогрессия (больше модуль сравнения; модуль может быть любой специфики), тем "ближе" сравнение к уравнению. Как задачу, так и решение ее придумал сам. Как потом заметил Н. М. Коробов, "на этой задаче можно учить круговому методу" (просто видно, где большие дуги и что они дают, а где малые). Эта статья - следующий шаг к $p$-адическому методу.

Осталась незамеченной.

1.6. "Распределение дробных долей многочленов специального вида", Вестник МГУ, № 3 (1962), с. 34-38. Продолжение 1.5, т.е. "набирал" на кандидатскую. Поместил здесь оценку Н. М. Коробова (назвал прямо теорему).

1.7. 'Проблема Варинга для сравнения по модулю, равному степени простого числа", Вестник МГУ, № 4 (1962), с. 28-38. Задачу придумал летом 1961 г. в г. Грозном (опять под виноградом в саду, где решил задачу про автоматы). Думал о проблеме Варинга ${ }^{70}$, об оценке $G(n)$, полученной И. М. Виноградовым. Придумал задачу и сразу же - решение. Главное - точный результат для аналога $G(n)$. В статье ясно видна идея $p$-адического метода ( $p$-адическая метрика); помогла работа 1.5. Схема решения - Виноградовский метод оценки $G(n)$, только в $p$-адической форме. Эта работа и породила $p$-адический метод в том виде, который потом помог развить теорию кратных сумм и т.п. Эта работа породила также работу 1.8 .

1.8. “О теореме о среднем”, Доклады АН СССР, т. 149, № 2 (1963), с. 245-248. Размышляя над работой 1.7 (ее идейной стороной; все время хотел и сейчас хочу найти истинный порядок $G(n)$ в проблеме Варинга), вдруг понял, что теорему о среднем И. М. Виноградова можно делать через сравнения (сдвиг в полной системе приводит к сравнениям). Это было весной (март) 1962 г. Сразу же написал доказательство. Рассказал Н. М. Коробову. Он стал ею заниматься также; сообщил, что может сделать какие-то улучшения в дзете и предложил опубликовать серию работ на эту тему (совместных). Первой и явилась эта статья (и последней). Я вставил фразу: "По основной идее эта работа близка к работе (3)", т.е. к 1.7. Конечно, Н. М. Коробов внес положительный вклад в оформление этой работы; она получилась лаконичной, четкой. Вся техника этой работы (плюс находки и идеи Г. И. Архипова ${ }^{71}$ ) применяется в теории кратных сумм. Это - p-адический метод в теории тригонометрических сумм.

${ }^{67}$ В Германии.

${ }^{68}$ Арнольда Шёнхаге и Фолькера Штрассена, содержит алгоритм умножения с оценкой сложности

$$
M(n)=O(n \log n \log \log n)
$$

cM. [19].

${ }^{69} \mathrm{C}$ использованием быстрого преобразования Фурье - Fast Fourier Transforms.

${ }^{70}$ Edward Waring. О проблеме Варинга см., например, [7; с. 95], см. также [11; с. 94].

${ }^{71}$ Геннадий Иванович Архипов, ученик А. А. Карацубы. 
На эту тему появилось много вариаций: С. Б. Стечкин ${ }^{72}$, Э. Бомбьери ${ }^{73}$, К. Чандрасекхаран $^{74}$, Г. И. Архипов.

Доказательство этой теоремы (в основных технических чертах) совпадает с доказательством И. М. Виноградова с заменой леммы о попаданиях на лемму о полной системе сравнений. Эта лемма была раньше (1942 г.) сформулирована Ю. В. Линником ${ }^{75}$. О ее существовании я не знал; доказательства ее также не было в печати. Ю. В. Линник также (1942 г.) дал ${ }^{76}$ другое доказательство теоремы Виноградова, и также $p$-адическое. Но у него в системе уравнений неизвестные заранее имеют специальный вид; и в его доказательстве много неясных мест; оно может быть и ошибочным. Эту идею Линника нельзя провести в жизнь, создавая теорию кратных сумм. Я же пользуюсь существованием сдвига и с его помощью делаю систему сравнений. Тогда же я подчеркнул, что этот новый $p$-адический метод сводит (через теорему о среднем) вопрос об оценке коротких сумм к вопросу о полных суммах.

1.9. "Тригонометрические суммы специального вида и их приложения", Известия АН СССР. Серия математическая, т. 28, № 1 (1964), с. 237-248. Задачу придумал сам, т.е. увидел, что если записывать Постниковский характер $\left(\bmod p^{n}\right)$ через exp, а потом сделать $p$-адический сдвиг $x \rightarrow x+p^{\lambda} y$, то получим ехр с показателем вида $f(x)=a_{0}+a_{1} x+a_{2} p^{\lambda+1} x^{2}+\cdots+a_{m} p^{(\lambda+1)(m-1)} x^{m}$, где $\left(a_{j}, p\right)=1$. Соответствующие суммы назвал $L$-суммами, оценил их с понижением вида $c / r^{2}$, приложил к $L$-рядам Постникова. Насколько могу понять, это были первые оценки, точность которых возрастала вместе с возрастанием длины интервала суммирования. При оценках таких сумм пользовался идеей Виноградова, т.е. $x \rightarrow x+p^{\lambda} y z$, и понижением степени многочлена за счет выбора $\lambda$ (эта идея идет от Гаусса, Вейля ${ }^{77}$, Морделла $^{78}$, Виноградова, Харди ${ }^{79}$-Литтлвуда ${ }^{80}$ и была также у Коробова; см. работу 1.6). Позднее на эту тему несколько работ написал Н. М. Коробов, а когда он изучал суммы с $f(x)=g^{x} / p^{n}$, которые также являются $L$-суммами, то не сослался даже на мою работу.

1.10. “Приложение № 4" к книге Хуа ${ }^{81}$. 1964. Обзор. Изложение $p$-адического доказательства теоремы о среднем Виноградова, сформулированы результаты по суммам и дзете Н. М. Коробова и по суммам и $L$-рядам - мои (также аналог проблемы Варинга, т.е. работы $1.5,1.7)$.

1.11. “О системах сравнений”, Известия АН СССР. Серия математическая, т. 29, № 4 (1965), с. 935-944. Н. М. Коробовым на Съезде ${ }^{82}$ (4-м) в Ленинграде (1961 г.) была поставлена задача об оценке сверху для числа решений системы сравнений - аналог теоремы о среднем Виноградова, но для сравнений. Я постоянно размышлял над ней. В общем виде решить ее не смог. Но построил модули, для которых эта задача решается с нужным ответом. Этому и посвящена работа. Статья послужила также источником другой -1.14 . Отрабатывался р-адический метод.

1.12. “Об оценке числа решений некоторых уравнений”, Доклады АН СССР, т. 165, № 1 (1965), с. 31-32. Стал думать над проблемой Варинга и оценкой $G(n)$. Ясно, что надо было иметь правильную оценку для $I_{k, n}(P)$ - числа решений уравнения

$$
x_{1}^{n}+\cdots+x_{k}^{n}=y_{1}^{n}+\cdots+y_{k}^{n}, \quad 0<x_{i}, y_{i} \leqslant P .
$$

\footnotetext{
${ }^{72}$ Сергей Борисович Стечкин.

${ }^{73}$ Enrico Bombieri.

${ }^{74}$ Komaravolu Chandrasekharan.

${ }^{75}$ Юрий Владимирович Линник.

${ }^{76}$ См., например, [7; с. 133-134], см. также [11; с. 133-134].

${ }^{77}$ Hermann Klaus Hugo Weyl.

${ }^{78}$ Louis Joel Mordell.

${ }^{79}$ Godfrey Harold Hardy.

${ }^{80}$ John Edensor Littlewood.

${ }^{81}$ Хуа Ло-кен. См. [20].

82 По-видимому, имеется в виду Четвертый всесоюзный математический съезд 1961 г.
} 
Поставил себе задачу: получить при заданном $k$ возможно лучшее понижение. Это и сделано. Доказана также аналогичная оценка для "выщербленной” системы уравнений.

1.13. “Системы сравнений и уравнения Варинговского типа", Доклады АН CCСР, т. 165, № 2 (1965), с. 274-276. Продолжение работы 1.12. Работы 1.12, 1.13 только в последние годы ${ }^{83}$ получили развитие $(я+$ Г.И. Архипов $\rightarrow$ новая оценка интеграла И. М. Виноградова).

1.14. “Теоремы о среднем и полные тригонометрические суммы”, Известия АН СССР. Серия математическая, т. 30, № 1 (1966), с. 183-206. Пытаясь решить задачу Н. М. Коробова об $N_{k, n}$ (см. работу 1.11$)$, придумал задачу об $N_{k, n}\left(q_{1}, \ldots, q_{n}\right)$ для "почти всех" $q_{1}, \ldots, q_{n}$ и решил ее. Обнаружилась удивительная связь: тех оценок для "выщербленных" систем уравнений, которые были получены мной на основе разработанного метода, хватало для решения этой задачи (для "почти всех"). Эта связь и этот эффект еще ни мной, ни кем другим до конца не осознан, хотя уже много получено из раздумий над этим (Г. И. Архипов, В. Н. Чубариков). Н. М. Коробов своих учеников на это направление "пускал", но не знаю, что они придумали (В. Быковский ${ }^{84}$, Соколинский ${ }^{85}$ ). В работе используется лемма 4 (Хуа) для выделения главного члена, которая затем "заиграла" во многих работах (Чубариков, Архипов, Митькин ${ }^{86}$ и др.). На Западе этой работы не знают (нет никаких сведений на этот счет).

Над ней стоит еще раз задуматься!

1.15. “Асимптотические формулы для некоторого класса тригонометрических сумм", Доклады АН СССР, т. 169, № 1 (1966), с. 9-11. Размышляя над проблемой Варинга, $G(n)$, решил получить асимптотику для тригонометрических сумм специального вида (т.е. хотел понять, как они себя ведут; пусть имеют частный вид, но зато на полном диапазоне длины - от самых коротких до самых длинных). Теорема 1 сформулирована неправильно главный член несколько другой (нет второго слагаемого, см. работу 1.22), хотя следствие из нее - правильное (оценка суммы). Обобщение этой работы было сделано Н. М. Коробовым ${ }^{87}$ (даже не теоремы, а следствия из нее, т.е. получены оценки); он вместо $f(x)=a x^{n}$ рассмотрел $f(x)=a x^{n}+a_{1} x^{n-1}+\cdots+a_{n-1} x$ с теми же результатами (опубликовано в Матем. заметках).

Таким образом, эта работа - начало теории правильного поведения модуля тригонометрической суммы в зависимости от длины суммирования.

1.16. “Метод тригонометрических сумм и теоремы о среднем", Математические заметки, т. 1, № 1 (1967), с. 99-110. Реферат докторской диссертации, защищенной в МИАНе (1966 г.), оппоненты И. М. Виноградов, Н. Г. Чудаков, А. И. Виноградов ${ }^{88}$. Постановки задач в диссертации и результаты.

1.17. “Об оценках полных тригонометрических сумм", Математические заметки, т. 1, № 2 (1967), с. 199-208. Есть суммы (полные с простым модулем), которые оцениваются лучше, чем по методу А. Вейля ${ }^{89}$. Класс таких сумм был обнаружен А. Г. Постниковым (из устных сообщений) и опубликован Н. М. Акулиничевым (учеником А. Г. Постникова). Я стал думать над этим; нашел еще много таких сумм. Далее “почти все” суммы оцениваются $\leqslant c \sqrt{n p}$. Будет ли так для “всех"? Этот вопрос поставил я и придумал ответ - решение для больших $n \asymp p / \ln p$ (отрицательный ответ). Там же поставил задачу: уменьшить значение $n$

\footnotetext{
${ }^{83}$ Написано в 1985 г.

${ }^{84}$ Виктор Алексеевич Быковский.

${ }^{85}$ Владимир Зиновьевич Соколинский.

86 Дмитрий Алексеевич Митькин.

${ }^{87}$ По-видимому, имеется в виду статья: Н. М. Коробов, “Двойные тригонометрические суммы и их приложения к оценке рациональных сумм", Матем. заметки, 6:1 (1969), 25-34.

${ }^{88}$ Аскольд Иванович Виноградов.

${ }^{89}$ André Weil.
} 
в моей теореме. До сих пор никто результата не усилил, хотя появился ряд статей (Д. А. Митькин, С.А. Степанов ${ }^{90}+$ А.Г. Постников), где обобщается мой результат и дается (другое?) доказательство (для сумм символов Лежандра).

Сейчас я думаю, что если $n \leqslant p^{1-\varepsilon}, \varepsilon>0, p \rightarrow+\infty$, то уже должна быть нетривиальная оценка полной суммы с многочленом в экспоненте; $p$ - простое число. Однако совсем неожиданно для меня в конечных полях моя гипотеза (тривиальность оценки при $n>q^{0.5+\varepsilon}$ ) оправдалась; это сделал в 1986 г. В. Зиновьев ${ }^{91}$, и это идет из теории кодирования! Неисповедимы пути Господни!

В этой же работе доказал ряд тождеств между суммами Гаусса и суммами с многочленами в экспоненте (теорема 5). Позднее Н. М. Коробов опубликовал половину этой теоремы (связь между суммами Гаусса и суммами с показательной функцией) без ссылок на мою теорему...

$* * * * * * * * * * * * * * * * * * * * * * * * * * * * * * * * * * * * * * * * * * * * * * * * * * * * * * * *$

1.18. “Об одной системе неопределенных уравнений”, Математические заметки, т. 4, № 2 (1968), 125-128. В статье даю равномерную оценку интеграла $J$ (И. М. Виноградова), которая обычно применяется при оценках сумм Г. Вейля, и даю также равномерную оценку суммы Г. Вейля по старшему коэффициенту. Работа - непосредственное продолжение работы 1.8 и, конечно, работ И. М. Виноградова по оценкам сумм Г. Вейля.

1.19. “Об одной асимптотической формуле”, Труды московского математического общества, т. 18 (1968), с. 77-82. Задачу поставил сам; она продолжает работы 1.5, $1.7,1.15$. Как и в работе 1.15 , допущена ошибка (лемма 4 ), хотя следствие - правильное (как и теорема статьи). Когда американцы переводили ${ }^{92}$ эту статью, послал им исправления. Они их учли, и появился перевод 1.20 .

1.20. “On an asymptotic formula”. Перевод 1.19 с моими исправлениями.

1.21. “Суммы характеров и первообразные корни в конечных полях", Доклады AH CCCP, т. 180, № 6 (1968), с. 1287-1289. Делал доклад на семинаре А. О. Гельфонда $^{93}$ по работе Д. Берджесса ${ }^{94}$ о его оценке суммы характеров; был 1967 г. Придумал новое доказательство теоремы Берджесса: сдвиг $x \rightarrow x+y z$ и $x \rightarrow x y^{-1}+z$. Рассказал в МИАНе Н. М. Коробову. Его (как всегда) увлекла эта идея, он стал активно заниматься и даже (как сказал он) получил улучшение (оказалось - ошибочно, так как на этой идее Берджесс все получил). Так как ничего нового я сразу не мог получить, то никакой статьи не публиковал. Затем сразу появилось две статьи о суммах характеров в конечных полях: Берджесса и Дэвенпорта ${ }^{95}-$ Льюиса ${ }^{96}$, где результат Берджесса переносился на поле степени 2 и, со значительным ухудшением, на поле степени $n \geqslant 2$. Я сразу же сделал для любой степени $n \geqslant 2$. Эту идею (дословно) потом использовал Берджесс в своей статье ${ }^{97} .$. Развитие идеи этой работы позволило получить мне все результаты с суммами характеров с простыми числами (см. ниже). Часто излагаю это в лекциях; Л. П. Постникова ${ }^{98}$ также читала где-то.

\footnotetext{
${ }^{90}$ Сергей Александрович Степанов.

${ }^{91}$ Виктор Александрович Зиновьев. См., например, статью: В. А. Зиновьев, С. Н. Лицын, "Нижние оценки полных рациональных тригонометрических сумм", УМН, 43:1(259) (1988), 199-200.

92 Журнал "Труды ММО", как и другие ведущие математические журналы СССР и России, выходит в двух вариантах, сначала на русском языке, а затем в переводе на английский.

${ }^{93}$ Александр Осипович Гельфонд.

${ }^{94}$ David A. Burgess.

${ }^{95}$ Harold Davenport.

${ }^{96}$ Donald John Lewis.

${ }^{97}$ По-видимому, имеется в виду статья: D. A. Burgess, "A note on character sums over finite fields", J. Reine Angew. Math., 255 (1972), 80-82.

98 Людмила Петровна Постникова.
} 
1.22. “О тригонометрических суммах”, Доклады АН СССР, т. 189, № 1 (1969), c. 31-34. Продолжение работы 1.15. Исправлена теорема и лемма из работы 1.15 и доказана новая теорема 1 об асимптотической формуле для почти всех сумм $S(a ; P, q)$ определенного класса. Приложений (работа) пока не нашла, хотя думал вставить в проблему Варинга.

1.23. “О суммах характеров с простыми числами”, Доклады АН СССР, т. 190, № 3 (1970), с. 517-518. На основе идеи работы 1.21 получена новая оценка суммы характеров от последовательности сдвинутых простых чисел, не тривиальная при длине $\geqslant q^{0.5+\varepsilon}$. Задача придумана И. М. Виноградовым (как применение его метода оценок сумм с простыми числами). Кроме И. М., никто серьезно этой проблематикой не занимался. Ю. В. Линник надеялся применить это к квазиримановой гипотезе (и для $L$-рядов), но ничего не вышло. У И. М. оценка не тривиальна при длине $\geqslant q^{0.75+\varepsilon}$.

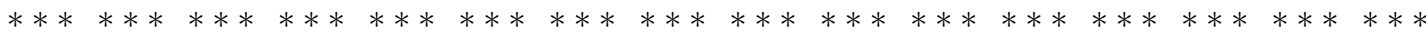

1.24. “Об оценках сумм характеров”, Известия АН СССР. Серия математическая, т. 34, № 1 (1970), с. 20-30. Работа является продолжением работы 1.21. В этой проблематике важно иметь не только нетривиальные оценки возможно более коротких сумм характеров, но также и по возможности более точные оценки пусть более длинных сумм (для теории $L$-рядов). Аналогичная работа есть у Берджесса. Я сделал это для конечных полей. Стоило бы продолжать это направление; никто этого не делал ${ }^{99}$ (может быть, в Англии было?).

1.25. “Суммы характеров с простыми числами”, Известия АН СССР. Серия математическая, т. 34, № 2 (1970), с. 299-321. Подробное изложение (с полными доказательствами) работы 1.23. Начало целой серии работ по оценкам сумм слагаемых вида $\chi(p+k)$. Надо внимательно все посмотреть и подумать над новыми приложениями этих результатов. Такая техника и такие идеи должны дать что-то хорошее (кроме того, что уже есть).

1.26. "Распределение произведений сдвинутых простых чисел в арифметических прогрессиях", Доклады АН СССР, т. 192, № 4 (1970), с. 724-727. Задачу придумал я, хотя (как потом узнал, мне написал об этом М. Ютила ${ }^{100}$ ) она уже была у Ю. В. Линника, М. Ютилы и других - гольдбаховы числа в арифметических прогрессиях. Задача придумана на такую идею: рассмотрим сравнение $u v+p \equiv l(D)$. Тогда число $J$ его решений равно

$$
J=\frac{1}{\varphi(D)} \sum_{\chi} \sum_{u, v} \chi(u v) \sum_{p} \chi(l-p) .
$$

Выделяя главный член, остаток $R$ оценим так:

$$
|R| \ll \max _{\chi \neq \chi_{0}}\left|\sum_{p} \chi(l-p)\right| \frac{1}{\varphi(D)} \sum_{\chi}\left|\sum_{u} \chi(u)\right|^{2},
$$

т.е. "бинарная" задача решается по схеме тернарной (пользуемся мультипликативностью задачи). Эту идею с блеском применил М. М. Петечук ${ }^{101}$ в задаче суммы $\tau_{k}(n), n \equiv l\left(\bmod p^{k}\right)$, $p \geqslant 3$ фиксированное (его кандидатская диссертация ${ }^{102}$ ). Совсем недавно (1985 г.) Г. Иванец и Дж. Фридлендер ${ }^{103}$ эту идею также использовали в задаче $\sum \tau_{k}(n), n \equiv l(\bmod D)$; Иванец знал о ней от нас; был у нас на семинаре, и М. Петечук об этом рассказывал. . .

\footnotetext{
${ }^{99}$ Написано в 1985 г.

${ }^{100}$ Matti Jutila.

${ }^{101}$ Михаил Михайлович Петечук, ученик А. А. Карацубы.

${ }^{102}$ См., например, статью: М. М. Петечук, "Сумма значений функции делителей в арифметических прогрессиях с разностью, равной степени нечетного простого числа", Изв. АН СССР. Сер. матем., 43:4 (1979), $892-908$.

103 John Benjamin Friedlander.
} 
Идея очень красивая; она “заиграла" и в других задачах (типа "большого решета"), но пока яркого ничего (кроме работы Петечука) нет. Надо бы еще подумать!

1.27. "Распределение степенных вычетов и невычетов в аддитивных последовательностях", Доклады АН СССР, т. 196, № 4 (1971), с. 759-760. Задачу придумал сам. Задача на идею двойных сумм $\chi(u+v)$ с возможностью представить $v$ в виде $v=x y$ и затем $\chi\left(u x^{-1}+y\right)$, т.е. продолжение все той же идеи из 1.21.

Следовало бы продолжить это!

1.28. “Суммы характеров с простыми числами, принадлежащими арифметической прогрессии", Известия АН СССР. Серия математическая, т. 35, № 3 (1971), c. 469-484. Продолжение исследований, начатых (и придуманных) И. М. Виноградовым с применением идеи работы 1.21 и ниже. Удалось не только “укоротить" длину суммы, но и снять ряд ограничений, которые раньше были. В лемме 5 применил такое соображение: умножая обе части сравнения вида $a(\ldots) \equiv B(\bmod D)$ на подходящее $b$, делал число $a b$, $a b(\ldots) \equiv b B(D), a b \equiv c(\bmod D), c \leqslant \sqrt{D}$, т.е. "загонял" неудобные числа в "малый" интервал. Работа в техническом отношении сложная, но хорошо отработана. Тема и результаты - наши, нашей школы теории чисел.

1.29. “Об одной арифметической сумме”, Доклады АН СССР, т. 199, № 4 (1971), c. 770-772. Задачу придумал я. Задача на применение идеи работы 1.26 плюс оценки сумм характеров специального вида. Продолжений не видел.

Следовало бы продолжить!

1.30. “Оценки тригонометрических сумм методом И. М. Виноградова и их применения", Труды МИАН СССР, т. 112, 1971, с. 241-255. Давно была задумка написать статью об оценке тригонометрических сумм с $F(x)$, зная поведение $F^{(k)}(x), k=k_{1}, \ldots, k_{r}$. Оценка была, но не было приложений. Посмотрел Е.К. Титчмарша 104 "Теорию дзеты" 105, нашел высокие моменты и проблему делителей Дирихле. Увидел, что из оценки И. М. Виноградова дзеты вида

$$
\zeta(\sigma+i t)=O\left(|t|^{c(1-\sigma)^{3 / 2}} \log |t|\right), \quad|t| \geqslant 2,
$$

можно сильно улучшить упомянутые результаты (моменты и Дирихле ${ }^{106}$ ). Доказательства очень простые, но результаты впечатляют. Так появилась статья. Еще в ней есть оценка суммы с быстро растущей $F(x)$. Результаты статьи, идеи ее и продолжение исследований были у нас $\left(\ddot{Е}_{\text {дгоров }}{ }^{107}\right.$, Пантелеева $\left.{ }^{108}\right)$, в Японии, в Югославии (Ивич $\left.{ }^{109}\right)$ и др. В 1985 г. А. Ивич прислал книгу "The Riemann zeta function", 1985 г. издания ${ }^{110}$. В ней на с. 382 говорится о статье H. E. Richert"11, "Einführung in die Theorie der Starken Riszschen Summierbarkeit von Dirichletreihen", Nachr. Akad. Wiss. Göttingen Math. Phys. (1960), 17-75, где получен результат

$$
\Delta_{k}(x)=O\left(x^{\alpha_{k}+\varepsilon}\right), \quad \alpha_{k} \leqslant 1-C k^{-2 / 3},
$$

и написано, что я его передоказал в 1971 г., т.е. в настоящей работе. Я посмотрел статью Рихерта. Действительно, там есть этот результат, но о нем, по-видимому, никто никогда не знал. И доказан он на 60 страницах, у меня же - на трех страницах. Мою работу сразу же

\footnotetext{
${ }^{104}$ Edward Charles Titchmarsh.

${ }^{105}$ CM. [21].

${ }^{106}$ То есть оценку остаточного члена в асимптотической формуле для суммы функций $\tau_{k}(n), n \leqslant x$, где $\tau_{k}(n)$ - число представлений $n$ в виде произведения $k$ сомножителей.

${ }^{107}$ Ж. Ёдгоров.

${ }^{108}$ Елена Ивановна Пантелеева-Деза.

${ }^{109}$ Aleksandar Ivić.

${ }^{110}$ По-видимому, имеется в виду книга: A. Ivić, "The Riemann Zeta-Function", John Wiley and Sons, New York, 1985.

${ }^{111}$ Hans-Egon Richert.
} 
стали уточнять, развивать, о работе же Рихерта не было никаких упоминаний. Наверное, делал он "через голову", моя же идея очень проста: оценка дзеты в окрестности прямой $\operatorname{Re} s=1$ используется прямо и только.

Таким образом, нечаянно обидел Рихерта, не сослался на него, так как не знал работы. При первом же удобном случае надо исправить эту оплошность.

Исправил (1995, Springer).

Говорил с Рихертом об этом в Обервольфахе ${ }^{112}$; в издании Springer-Verlag моего учебника 113 “Основы аналитической теории чисел, 2-е изд.", в задачах указан результат Рихерта и его работа.

1.31. “Проблема делителей Дирихле в числовых полях", Доклады АН СССР, т. 204, № 3 (1972), с. 540-541. Посмотрел, куда еще можно применить идеи работы 1.30. Прочитал работу Э. Ландау ${ }^{114} 1912$ г. и все результаты ее усилил соответствующим образом.

1.32. “Равномерная оценка остаточного члена в проблеме делителей Дирихле", Известия АН СССР. Серия математическая, т. 36, № 3 (1972), с. 475-483. Задачу (равномерную оценку остатка) придумал сам. Хотел через получаемую асимптотику вывести асимптотический закон распределения простых чисел. Сама работа получилась интересной. Нашла применения также лемма 1 в других работах (на нее ссылаются). Ее в основном и цитируют на Западе.

1.33. “О некоторых проблемах теории простых чисел, связанных с методом И. М. Виноградова", Труды МИАН СССР, т. 132, 1973, с. 257-261. Доклад, прочитанный мной на пленарном заседании Международной конференции 1971 г., посвященной 80-летию И. М. Виноградова. Передо мной доклад читал Э. Бомбьери. С идейной стороны отображен метод Виноградова оценок сумм слагаемых $\chi(p+k)$ и полученные здесь результаты. Все это очень нравилось Ю. В. Линнику.

1.34. “Об оценках снизу сумм характеров от многочленов”, Математические заметки, т. 14, № 1 (1973), с. 67-72. Продолжение (перенесение на суммы символов Лежандра) работы 1.17. Был ряд "продолжателей" (Д. А. Митькин, С. А. Степанов), которые ничего нового не сделали. Совсем недавно В. Зиновьев получил в конечных полях то, что я хотел: полная сумма почти тривиально оценивается, если $n=q^{0.5-\varepsilon}$. Сама же моя гипотеза для полей степени 1 , наверное, не верна. Думаю, что если $f \not \equiv g^{2}(\bmod p)$, степень $f$ равна $n \leqslant p^{1-\varepsilon}, p \rightarrow \infty$, то $\sum_{x=1}^{p}(f(x) / p)=\overline{\bar{o}}(p) ; p-$ простое число.

Может, все это пригодится в теории кодов; по крайней мере В. Зиновьев и другие этим активно занимаются и смотрят как "кодировщики".

Сейчас (1997 г.) Л.А. Бассалыго ${ }^{115}$ и В.А. Зиновьев в конечных полях получили, что оценка А. Вейля является точной, т.е.

$$
|S|=(n-1) \sqrt{q} \text {. }
$$

Сумма в конечном поле сводится к обычной прямой сумме с квадратным многочленом в экспоненте, последняя же точно вычисляется (сумма Гаусса) и получается точный результат.

\footnotetext{
${ }^{112}$ Математический исследовательский институт на юге Германии, где проводятся математические конференции по отдельным дисциплинам; А. А. Карацуба посещал Обервольфах в 1986 г., в 1988 г. и в 1991 г.

${ }^{113}$ CM. [8].

${ }^{114}$ Edmund Landau. По-видимому, имеется в виду работа E. Landau, "Über die Anzahl der Gitterpunkte in gewissen Bereichen", Nachr. Akad. Wiss. Gottingen Math. Phys., 6 (1912), 687-771.

${ }^{115}$ Леонид Александрович Бассалыго. См., например, статью: Л. А. Бассалыго, В. А. Зиновьев, "Многочлены специального вида над конечным полем с максимальным модулем тригонометрической суммы", УМН, 52:2(314) (1997), 31-44.
} 


\section{Toм 2}

2.1. “Среднее значение модуля тригонометрической суммы”, Известия АН СССР. Серия математическая, т. 37, № 6 (1973), с. 1203-1227. В одном из разговоров с С. Б. Стечкиным возник вопрос об упрощенной верхней границе $J$, равномерной по всем параметрам. Насколько помню, мечтой С. Б. Стечкина и была оценка ${ }^{116}(2) \ldots$

В работе есть несколько интересных соображений, в частности лемма 9, теорема 2. Позднее соображения, примененные при доказательстве теоремы 3 , были использованы Г. И. Архиповым и В.Н. Чубариковым в работах по теории кратных сумм.

$* * * * * * * * * * * * * * * * * * * * * * * * * * * * * * * * * * * * * * * * * * * * * * * * * * * * * * *$

2.2. “Суммы характеров по последовательности сдвинутых простых чисел и их применения", Математические заметки, т. 17, № 1 (1975), с. 155-159. Доклад, который я прочитал на Всесоюзной конференции по теории чисел в Вильнюсе (май, 1974 г.). История оценок сумм характеров, арифметические задачи, связанные с этим, задачи И. М. Виноградова, его гипотезы, последние достижения, мои результаты. Объяснены идейные истоки, позволившие продвинуться в этих вопросах.

2.3. “О некоторых проблемах современной аналитической теории чисел”, Математические заметки, т. 17, № 2 (1975), с. 341-350. Доклад, который я прочитал на годичном собрании Отделения математики АН СССР (зима, 1974 г.). Здесь рассказано о многомерной проблеме делителей Дирихле, моих результатах, а также о работе 2.2.

2.4. “О некоторых арифметических задачах с числами, имеющими малые простые делители", Acta Arithmetica, Vol. 27 (1975), p. 489-492. Этот том был посвящен памяти Ю. В. Линника. В статье сформулированы теоремы, которые продолжают исследования Линника. Эти теоремы я неоднократно обсуждал с Линником, который хорошо понимал арифметику проблемы Варинга и все, что с ней связано. Развитие этой тематики неожиданно проявилось в моей работе 3.19 .

2.5. “Тригонометрические суммы и их применения", Proceedings of the International Congress of Mathematicians (Vancouver, 1974), Vol. 1, 1975, p. 365-368. Доклад, который ... я не смог прочитать, так как не был в Ванкувере. Короткое общее соображение о задачах типа задач работы 2.4 и идейные истоки, позволившие продвинуться в многомерной проблеме делителей.

2.6. "Experimente mit Automaten", Elektronische Informationsverarbeitung und Kybernetik, Band 11 (1975), 611-612. Короткий доклад по моей работе 1.1; хотел еще раз подчеркнуть, что задачу решил я... Там же сформулировал задачу: получить нижнюю оценку вида

$$
f_{A}(n, 2,2) \geqslant \frac{(n-1)(n-2)}{2}+1 .
$$

Доклад прочитан в Берлине (первый раз был за границей) на международном симпозиуме по кибернетике ${ }^{117}$. Решена ли моя задача - не знаю.

${ }^{116}$ То есть оценка

$$
J=J_{k, n}(P) \leqslant e^{c n^{3} \log n} P^{2 k-\left(n^{2}+n\right) / 2},
$$

где $J$ - интеграл Виноградова, $n \geqslant 2, P \geqslant 1, k \geqslant c_{1} n^{2} \log n$ и $c>0, c_{1}>0$ - абсолютные постоянные.

${ }^{117}$ International Symposium "Diskrete Mathematik und Anwendungen in der Mathematischen Kybernetik", Berlin, 1974. 
2.7. "Berechnungen und die Kompliziertheit von Beziehungen", Elektronische Informationsverarbeitung und Kybernetik, Band 11 (1975), s. 603-606. См. работу 2.6. Рассказал о проблематике быстрых вычислений, о том, что основной идейный толчок в этой области был дан моей работой 1.4, что затем только развивали мою идею, не внося принципиально новых соображений. ., о работах Ю. В. Бендерского ${ }^{118}$ (деление, извлечение корня) и сформулировал задачу о быстром вычислении (простейших) трансцендентных функций. С помощью АГС ${ }^{119}$ задачу решил Р. Брент ${ }^{120}$ (R. P. Brent, "Fast Multiple-Precision Evaluation of Elementary Functions", ACM, 23:2 (1976), 242-251), причем как само собой разумеющееся говорил о задаче (хотя четко она была поставлена у меня и Бендерского ${ }^{121}$ ), об итеративном методе (все из моего доклада), но не сослался на мой доклад ${ }^{122}$.

$* * * * * * * * * * * * * * * * * * * * * * * * * * * * * * * * * * * * * * * * * * * * * * * * * * * * * * *$

Вся тематика быстрых вычислений грешит такими "ссылками".

$* * * * * * * * * * * * * * * * * * * * * * * * * * * * * * * * * * * * * * * * * * * * * * * *$

Принципиально новый метод (метод БВЕ ${ }^{123}$ ) и принципиально новые результаты получены здесь Е. А. Карацубой (1989-2002 гг.). Все опубликовано, реализовано в виде программ.

2.8. “Об одной системе сравнений”, Математические заметки, т. 19, № 3 (1976), c. 389-392. В. Н. Чубариков (был аспирантом) сдавал отчет по работам Ю. В. Линника; рассказывал (меня в то время интересовала проблема Гильберта-Камке ${ }^{124}$, которую потом решил Г. И. Архипов) работу ${ }^{125}$ Линника из УМН, 14:3 (1959), 153-160; был при этом С. М. Воронин $^{126}$. Вдруг видим ошибку в работе Линника. Исправить не можем, и на этой ошибке принципиально построено все доказательство. Даю Чубарикову месяц-два на исправление, на то, чтобы нашел правильное доказательство. Не получилось. Злюсь, ругаю его. Решил сам посмотреть, шел из МИАНа рассерженный на Володю, на задачу; около угла к автобусу № 57 сообразил, как ее сделать. Дома все оформил; правильно. Так появилась теорема. Ее чуть уточнил (константу) К. К. Марджанишвили ${ }^{127}$. Г. И. Архипов (а потом В. Н. Чубариков) пользовались ею и ее идеями в своих исследованиях по Гильберту-Камке и простым числам.

\section{9. “О распределении значений неглавных характеров”, Труды МИАН СССР,} т. 142 (1976), с. 156-164. Издавали сборник, посвященный 85-летию И. М. Виноградова. Мне хотелось написать статью, прямо продолжающую исследования И. М. Посмотрел его работы; увидел $\chi(w+k), w=p_{1} \cdots p_{r}$. Сделал подобно работам $1.23,1.25,1.26,1.28$. Техника и идеи - из этих же работ. В 1985 г. Гавхар Негматова ${ }^{128}$ продолжила эти работы (Докл. AH Тадж. ССР, 28:4 (1985), 193-197), защитила кандидатскую диссертацию.

\footnotetext{
${ }^{118}$ Юрий Викторович Бендерский, ученик А. А. Карацубы, написавший под его руководством дипломную работу на механико-математическом факультете МГУ; в настоящее время живет и работает в г. Иерусалиме.

${ }^{119}$ Метод АГС - это метод арифметико-геометрических средних Гаусса.

${ }^{120}$ Richard Pierce Brent.

${ }^{121}$ См. статью: Ю.В. Бендерский, "Быстрые вычисления", Докладъ Академии Наук CCCP, 223:5 (1975), 1041-1043.

122 Доклад был сделан A.A. Карацубой в 1974 г. в Берлине на международном симпозиуме "Diskrete Mathematik und Anwendungen in der Mathematischen Kybernetik".

${ }^{123}$ Метод БВЕ - это метод быстрого вычисления E-функций, который дает возможность вычислять $E$-функции Зигеля и, в частности, $\exp (x)$ для любого аргумента $x$ со сложностью, близкой к оптимальной.

124 Проблемой Гильберта-Камке называется круг задач, связанных с исследованием вопроса об одновременном представлении натуральных чисел суммами ограниченного числа натуральных слагаемых соответствующего вида. David Hilbert. Erich Kamke. См. статьи: D. Hilbert, "Beweis für die Darstellbarkeit der ganzen Zahlen durch eine feste Anzahl $n$-ter Potenzen (Waringsches Problem)", Math. Ann., 67 (1909), 281-300; E. Kamke, "Verallgemeinerungen des Waring-Hilbertschen Satzes", Math. Ann., 83:1-2 (1921), 85-112.

${ }^{125}$ Имеется в виду работа: Ю.В. Линник, "Некоторые замечания об оценках тригонометрических сумм", УМH, 14:3(87) (1959), 153-160.

${ }^{126}$ Сергей Михайлович Воронин, ученик А. А. Карацубы.

${ }^{127}$ Константин Константинович Марджанишвили.

${ }^{128}$ Гавхар Дехкановна Негматова, ученица А. А. Карацубы.
} 
2.10. “Верхняя граница модуля кратной тригонометрической суммы” (совместно с Г. И. Архиповым и В.Н. Чубариковым), Труды МИАН СССР, т. 143 (1977), с. 3-31. Это 2-й том к 85-летию И. М. Виноградова. Г.И. Архипов своей работой ${ }^{129}(M a-$ тем. заметки, 17:1 (1975), 143-153) положил начало теории кратных тригонометрических сумм (KTC). Задачу построения такой теории поставил я; ее решил Г. И., причем первые свои сообщения он так плохо делал (на моем семинаре), что я долго не мог понять и поверить, что все правильно. Потом понял. Г.И. и В. Н. ${ }^{130}$ опубликовали совместную работу по КТС в ИАН ${ }^{131}$ (1976 г.). Стали поступать сообщения, что в эту тематику встревает Н. М. Коробов (как всегда!) и вставляет еще свою ученицу. Боясь, что все "уплывет", если активно не заняться КТС, я предложил Г.И. и В.Н. вместе заняться этой темой и написать совместную статью. Так появилась эта работа. Она очень “сырая". Большую ее часть написал В. Н., я и Г.И. только "контролировали". В ней немало огрехов; в частности, обозначение на с. 4 $\left(\sum \cdots \sum \sum\right)$, придуманное "не от хорошей жизни" и переписанное затем "последователями". Тем не менее статья была первой в серии работ, составивших фундамент теории КТС. В ней есть ряд оригинальных утверждений.

2.11. "Распределение значений символов Лежандра от многочленов с простыми числами", Доклады АН СССР, т. 238, № 3 (1978), с. 524-526. Занимаясь суммами характеров, постоянно думал о сдвиге $x \rightarrow x+y z \rightarrow x y^{-1}+z$. Пытался воспользоваться этим, чтобы оценить короткую сумму $\sum_{x} \chi(f(x)), f$ - многочлен; ничего это не дало; однако когда посмотрел $\sum_{p \leqslant Y} \chi(f(p))$, то получилась нетривиальная оценка при $Y \geqslant q^{0.75+\varepsilon}$ (т.е. длина меньше $q$ и ровно то, что было у И. М. для $\chi(p+k))$; правда, оценка из гипотезы, еще не доказанной. Без всяких гипотез, т.е. безусловный, результат получен для $f$ второй степени. На это также мне указал в письме А. И. Виноградов. Получился ряд арифметических следствий.

Считаю эту работу одной из лучших во всей теории характеров.

2.12. “Суммы символов Лежандра от многочленов второй степени с простыми числами", Известия АН СССР. Серия математическая, т. 42, № 2 (1978), с. 315324. Подробное изложение работы 2.11. Перенесена Г. Негматовой на $w=p_{1} \cdots p_{k}$. Очень важная и хорошая тема и работа.

2.13. “Об интеграле И. М. Виноградова” (совместно с Г.И. Архиповым), Доклады АН СССР, т. 239, № 4 (1978), с. 764-765. Была моя старая идея делать теорему о среднем для малых $k$. Прикидки давали что-то новое. Предложил Г. И. посмотреть эту идею внимательно. И вдруг он заявляет, что получается

$$
P^{k} \ll J \ll P^{k(1+\varepsilon)}, \quad 1 \leqslant k \leqslant \varepsilon^{2} n^{2} .
$$

Для меня это было полной неожиданностью. Вместо $P^{2 k-c k}, c<1, c$ - постоянная, получилось $c=1+O(\varepsilon)$. Мы с Г. И. Архиповым опубликовали статью; развивали далее эту идею. Позднее ученик Н. М. Коробова Соколинский "проехал" по этой работе. Сейчас (1986 г.) ученица Г. И. Архипова Оля Тырина ${ }^{132}$ довела идею и утверждения до совершенства.

2.14. "Новая оценка интеграла И. М. Виноградова" (совместно с Г. И. Архиповым), Известия АН СССР. Серия математическая, т. 42, № 4 (1978), с. 751-762. Подробное изложение работы 2.13. Очень отработано изложение теоремы о среднем (простейшая ситуация в общей теореме). Этим изложением я часто пользуюсь. Сама теорема о среднем в таком изложении - одна из красивейших теорем математики.

\footnotetext{
${ }^{129}$ Имеется в виду работа: Г. И. Архипов, “Теорема о среднем значении модуля кратной тригонометрической суммы", Матем. заметки, 17:1 (1975), 143-153.

${ }^{130}$ Г. И. Архипов и В. Н. Чубариков.

${ }^{131}$ Имеется в виду статья: Г. И. Архипов, В.Н. Чубариков, “Кратные тригонометрические суммы”, Изв. АН СССР. Сер. матем., 40:1 (1976), 209-220.

${ }^{132}$ Ольга Васильевна Тырина.
} 
2.15. “Точная оценка числа решений одной системы диофантовых уравнений" (совместно с Г. И. Архиповым и В.Н. Чубариковым), Известия АН СССР. Серия математическая, т. 42, № 6 (1978), с. 1187-1226. Продолжение 2.10 и одна из самых полных (по теореме о среднем для КТС) работ. Если теорема о среднем для тригонометрических сумм - одна из лучших теорем, то теорема 1 этой статьи - сверхлучшая; ее доказательство, доказательство основной леммы и леммы о полной системе сравнений - блеск. Все уже мы отработали (сидели на кафедре ${ }^{133}$ и предложение за предложением, последовательно отрабатывая, писали статью). В таком виде теорема о среднем вошла в монографию ${ }^{134}$. Теорема 2 аналог (для кратного случая) теоремы работы 2.1. Здесь же - оценки снизу, которые показывают точность результата. Ничего подобного в мире не было (по сложности и красоте).

2.16. “Асимптотика одной арифметической суммы”, Математические заметки, т. 24, № 6 (1978), с. 737-740. Работа родилась из работ 1.29 и 2.12. Придумал задачу я, написал. Хотя и любопытная работа, но продолжений пока нет. Стоило бы подумать о продолжении!

2.17. "Распределение дробных долей многочленов от нескольких переменных" (совместно с Г.И. Архиповым и В.Н. Чубариковым), Математические заметки, т. 25, № 1 (1979), с. 3-14. Приложение нашей теории КТС. Оригинальной является теорема 1 о совместном распределении и теорема 3 о дробных долях при условии, что переменные еще где-то лежат ${ }^{135}$. Вся статья - плод раздумий над задачами, которые есть в теории КТС и которых нет в теории сумм Г. Вейля (однократных).

Это направление еще получит свое развитие. $\mathrm{K}$ простым числам все это уже применено В. Н. Чубариковым ${ }^{136}$. Но много здесь еще не додумано и не сделано.

2.18. "Показатель сходимости особого интеграла проблемы Терри" (совместно с Г. И. Архиповым и В. Н. Чубариковым), Доклады АН СССР, т. 248, № 2 (1979), c. 268-272. В МИАНе ( $\approx 1978$ г.) ко мне неоднократно подходил сотрудник Ю. В. Прохорова $^{137}$ Резо Гамкрелидзе ${ }^{138}$ с вопросами об оценке тригонометрических интегралов - простых и кратных. K тому времени имел свои оригинальные оценки В. Н. Чубариков. Я стал снова думать об интегралах, "завел" Г. И. Архипова и В. Н. Чубарикова на решение старой задачи Хуа Ло-кена о показателе сходимости. Вроде, все должно было получиться, но не получалось до конца. Неоднократно втроем сидели на кафедре и думали над задачей. Выход (и решение) нашел Г. И. Архипов, который понял, что для решения нужно (см. лемму $\left.{ }^{139}\right)$, и это сразу же было сделано.

Теорема, а также лемма - очень хорошие утверждения, которые еще найдут применения, и не только в аналитической теории чисел. Ю. В. Прохоров неоднократно (в разных докладах) упоминал об этих исследованиях (им все это надо для статистики и вероятности).

\footnotetext{
${ }^{133}$ На механико-математическом факультете МГУ им. М. В. Ломоносова, где все они преподавали.

${ }^{134}$ См. [5], см. также [7], [11].

${ }^{135}$ То есть при условии, что переменные $x_{1}, \ldots, x_{r}$ принимают значения, принадлежащие некоторой области $\Omega_{r}$.

${ }^{136}$ См., например, статью: В. Н. Чубариков, “Оценки кратных тригонометрических сумм с простыми числами", Изв. АН СССР. Сер. матем., 49:5 (1985), 1031-1067.

${ }^{137}$ Юрий Васильевич Прохоров.

${ }^{138}$ Николай Георгиевич Гамкрелидзе.

139 Лемма. Пустъ $n \geqslant 1, f(x)=\alpha_{n} x^{n}+\cdots+\alpha_{1} x$,
}

$$
\beta_{r}(x)=\frac{1}{r !} f^{(r)}(x), \quad r=1, \ldots, n, \quad H=H\left(\alpha_{n}, \ldots, \alpha_{1}\right)=\min _{0 \leqslant x \leqslant 1} \sum_{r=1}^{n}\left|\beta_{r}(x)\right|^{1 / r} .
$$

Тогда для интеграла $J=\int_{0}^{1} \exp [2 \pi i f(x)] d x$ справедлива оценка

$$
|J| \leqslant \min \left(1 ; 6 e n^{3} H^{-1}\right) .
$$


Сейчас $\left(1997\right.$ г.) Д. А. Попов ${ }^{140}$ применил наши оценки в томографии и кратных рядах Фурье.

2.19. “Тригонометрические интегралы" (совместно с Г.И. Архиповым и В.Н. Чубариковым), Известия АН СССР. Серия математическая, т. 43, № 5 (1979), c. 971-1003. Полное изложение работы 2.18 и еще перенесение на кратный случай. Кратный случай не сделан полностью. Остались нерешенными задачи о показателе сходимости для кратных интегралов. Здесь должна быть своя красивая и стройная теория (может оказаться очень сложной), она еще не создана. Наша статья - первый шаг здесь. Мы ставили общую задачу (в статье), но пока нет никаких сдвигов (принципиальных). Думаю, что эта теория найдет применения в приложениях. Выяснилось, что подобные, но более слабые и "сырые" результаты были получеы статистиками С. М. Садиковой ${ }^{141}$, В. В. Юринским ${ }^{142}$; они опирались на Ван дер Корпута ${ }^{143}$. Наши же соображения - аналог Виноградовской идеи о попаданиях $^{144}$ (или Эйлеровской - об $u$-числах в проблеме Варинга) - линейная система уравнений с большим определителем (см. лемма 1).

В статье много идей, которые стоило бы развивать дальше!

2.20. “Об одной системе диофантовых уравнений" (совместно с Г. И. Архиповым и В.Н. Чубариковым), Доклады АН СССР, т. 252, № 2 (1980), с. 275-276. Развитие теории КТС. Сформулирована теорема о среднем, которая учитывает длину изменения каждой переменной по существу. Здесь - оригинальная идея "выбирать" неизвестные в количестве, пропорциональном длине его изменения ${ }^{145}$. Идею, вроде, предложил я; техническое осуществление сделано Г. И. Архиповым и В. Н. Чубариковым.

2.21. "Равномерные оценки кратных тригонометрических сумм" (совместно с Г. И. Архиповым и В. Н. Чубариковым), Доклады АН СССР, т. 252, № 6 (1980), c. 1289-1291. Приложение работы 2.20 к оценкам соответствующих сумм. Оригинальной является лемма о кратности пересечений, доказанная Г. И. Архиповым.

2.22. “Кратные тригонометрические суммы и их приложения" (совместно с Г. И. Архиповым и В.Н. Чубариковым), Известия АН СССР. Серия математическая, т. 44, № 4 (1980), с. 723-781. Полное изложение работ 2.20, 2.21 и еще многое другое. Задачу поставили мы сами в своей монографии ${ }^{146}$ (Tp. МИАН, 151 (1980)). В статье даем ее решение. Много интересных находок: лемма 2 (Г. И. Архипов) и все другие леммы (над каждой стоит еще подумать и посмотреть ее дальнейшее развитие), теорема 1, оценки снизу, леммы о кратности пересечений и леммы 7 и 8 (Г.И. Архипов), лемма 10 (Г. И. Архипов и В. Н. Чубариков). Есть также здесь и приложения. Статью следует внимательнейшим образом еще раз посмотреть, обдумать и развивать дальше. Много еще здесь можно сделать.

\section{Toм 3}

3.1. “О расстоянии между соседними нулями дзета-функции Римана, лежащими на критической прямой", Труды МИАН СССР, т. 157 (1981), с. 49-63. Был

\footnotetext{
140 Дмитрий Александрович Попов. См., например, статью: Д. А. Попов, "Восстановление характеристических функций в двумерной радоновской томографии”, УМН, 53:1(319) (1998), 115-198.

${ }^{141}$ Светлана Михайловна Садикова.

142 Вадим Владимирович Юринский.

143 Johannes van der Corput. Имеется в виду “лемма Ван дер Корпута", см. статью: J. G. Van der Corput, "Zahlentheoretische Abschätzungen", Math. Ann., 84 (1921), 53-79.

144 О лемме "о попаданиях" см., например, [7; с. 87], см. также [11; с. 85].

145 Чтобы правильно учесть вклад каждой переменной в общее число решений системы уравнений, каждая переменная разбивается на арифметические прогрессии с разностью, равной степени простого числа и пропорциональной длине интервала изменения этой переменной.

${ }^{146}$ CM. [5].
} 
первый раз в Чехословакии (1975 г.); поехал в Братиславу; Бржетислав Новак ${ }^{147}$ советовал обратить внимание на оригинального математика там - Я. Мозера ${ }^{148}$. Познакомился с Яном Мозером. Затем появилась его работа ${ }^{149}$ (1976 г., 1979 г.) о существенном улучшении результата Харди-Литтлвуда (нуль $\zeta(1 / 2+i t)$ на $(T, T+H), H=T^{1 / 6+\varepsilon}$ вместо $\left.H=T^{1 / 4+\varepsilon}\right)$. В ней была неточность; обнаружил ее С. М. Воронин на моем семинаре. Затем делал доклад Г. И. Архипов. Мы поняли, как исправить работу, оставаясь в круге тех же идей. Написал Я. Мозеру. Исправляя его работу, увидел, как ее уточнить $\left(H=T^{5 / 32+\varepsilon}\right)$, но не хотел публиковать, хотя была в этой работе одна оригинальная мысль (специальные тригонометрические суммы $\rightarrow$ переворот $\rightarrow$ оценка).

Издавали юбилейный сборник Трудов (90-летие И. М. Виноградова). Решил поместить эту оценку и придумал (и решил) задачу о нулях $Z^{(k)}(t)$. Получил (обнаружил) эффект "сближения" нулей, или эффект "осцилляции" $Z(t)$. Позднее (с подачи, по-видимому, Х. Монтгомери $\left.^{150}\right)$ нулями $\zeta^{(k)}(1 / 2+i t)$ занялся его ученик Б. Конри ${ }^{151} \ldots$ Потом улучшениями (без дополнительных идей) занимался А. Ивич (со своей версией истории этого вопроса).

Эта работа научила меня дзете; она - первая моя работа по дзете.

Идея Я. Мозера об использовании оценок тригонометрических сумм (недиагональные члены) является основной в этом круге проблем.

3.2. “Об одной задаче с простыми числами”, Доклады АН СССР, т. 259, № 6 (1981), с. 1291-1293. Вдруг увидел, что задача И. И. Пятецкого-Шапиро $\left[n^{c}\right]=p$ порождает целый круг задач типа $\left[n^{c}\right]=m^{2}$ и т.п.; однако обнаружил, что этой темой уже занимались (в частности, Б.И. Сегал ${ }^{152}$ рассмотрел $\left.\left[n^{c}\right]+\left[m^{c}\right]=N\right)$. Тем не менее сделал теорему $p^{r}=$ $\left[n^{c}\right], r \geqslant 1$, и аддитивную задачу $p^{r}+\left[n^{c}\right]=N$. Эти теоремы самые малые по плотности. В настоящее время этим будет заниматься С. Гриценко ${ }^{153}$.

3.3. “О локальном представлении нуля формой”' (совместно с Г. И. Архиповым), Известия АН СССР. Серия математическая, т. 45, № 5 (1981), с. 948-961. Г. И. Архипов сделал ${ }^{154}$ проблему Гильберта-Камке (1980 г.). Я обратил его внимание на схожесть с гипотезой Артина ${ }^{155}$ о локальном представлении нуля формой. Он сказал, что думал на эту тему, но ничего не вышло. Предложил подумать вместе. Этим занимались майские праздники (1981 г.). Узнали, что гипотеза Артина уже опровергнута. Через три дня после упорных усилий (тыканий и блужданий) придумали свое (было это в Ленинке ${ }^{156}$ ). Сразу поняли, что все дело в "выщербленных" системах сравнений, долго не могли доказать (2 дня) основную лемму, а потом придумали ${ }^{157}$.

В Минске ученик В. Г. Спринджука ${ }^{158}$ занялся и сделал то, что мы не доделали, но могли сразу сделать. Поняв, что эта "доделка" нам "выйдет боком", послали заметку в УМН 159 (1982 г.).

${ }^{147}$ Bretislav Novak, профессор Карлова университета в Праге, один из самых близких друзей А. А. Карацубы на протяжении всей жизни, со времени их совместного обучения в аспирантуре мехмата МГУ.

148 Ján Mózer.

${ }^{149}$ Имеется в виду работа: Ян Мозер, “Об одной теореме Харди-Литтлвуда в теории дзета-функции Римана", Acta Arith., 31 (1976), 45-51; Добавление, Acta Arith., 35 (1979), 403-404.

${ }^{150}$ Hugh Lowell Montgomery.

${ }^{151}$ John Brian Conrey.

152 Бенцион Израилевич Сегал.

${ }^{153}$ Сергей Александрович Гриценко, ученик А. А. Карацубы.

${ }^{154}$ См., например, статью: Г. И. Архипов, "О проблеме Гильберта-Камке", Изв. АН CCCP. Сер. матем., 48:1 (1984), 3-52.

${ }^{155}$ Emil Artin. О гипотезе Артина см., например, [7; с. 338], см. также [11; с. 361].

${ }^{156}$ Российская государственная библиотека, с 1925 г. по 1992 г. Государственная библиотека СССР им. В. И. Ленина.

${ }^{157}$ Результаты были опубликованы в работе [22].

${ }^{158}$ Владимир Геннадьевич Спринджук.

${ }^{159}$ Cм. [23].
} 
Потом еще были публикации на Западе на эту тему... З. И. Боревич ${ }^{160}$ и И. Р. Шафаревич ${ }^{161}$ поместили нашу теорему в 3 -е издание ${ }^{162}$ своей "Теории чисел", 1985 г.

$* * * * * * * * * * * * * * * * * * * * * * * * * * * * * * * * * * * * * * * * * * * * * * * * * * * * * *$

3.4. “О представлении нуля формой в поле $p$-адических чисел” (совместно с Г.И. Архиповым), Доклады АН СССР, т. 262, № 1 (1982), с. 11-13. Краткое изложение результатов работы 3.3 .

3.5. “Об одной задаче теории сравнений” (совместно с Г. И. Архиповым), Успехи математических наук, т. 37, № 5(227) (1982), с. 161-162. Статья написана вдогонку к работе 3.4. Опубликовали быстро, и этому помог А. А. Мальцев ${ }^{163}$. Тем не менее, на Западе стараются эту работу не заметить... Остались нерешенными наши задачи (гипотезы). Стоило бы заняться ими!

3.6. “Особые случаи теории кратных тригонометрических сумм" (совместно с Г.И. Архиповым и В.Н. Чубариковым), Известия АН СССР. Серия математическая, т. 47, № 4 (1983), с. 707-784. Принципиально новая тема теории КТС (в однократных ничего похожего нет). Переменные могут существенно отличаться друг от друга (сильно отличаются длины промежутков их изменения). Например, двукратная сумма по существу может быть однократной. И все это надо уловить. Этому и посвящена работа. "Перераспределение", т.е. переход от точек первого класса к точкам второго, полностью проделано Г.И. Архиповым; это его идея, и в основном вся работа сделана Г.И. Архиповым и В.Н. Чубариковым. Я - руководитель и "шлифовальщик" изложения, доказательств.

Одна из самых могучих работ теории КTC.

3.7. "Новые равномерные оценки кратных тригонометрических сумм" (совместно с Г.И. Архиповым и В.Н. Чубариковым), Доклады АН СССР, т. 272, № 1 (1983), с. 11-12. Краткое изложение результатов статьи 3.6. В конце статьи говорится о нерешенной проблеме Гильберта-Камке для многомерной системы.

Ее уже сделали Г. И. Архипов и В.Н. Чубариков ${ }^{164}$.

3.8. “О нулях дзета-функции Римана на коротких промежутках критической прямой”, Доклады АН СССР, т. 272, № 6 (1983), с. 1312-1314. Усиливается соответствующий результат Я. Мозера (у него $H=T^{5 / 12+\varepsilon}$, у меня $H=T^{27 / 82+\varepsilon}$ ). Сама теорема Мозера - это первый сдвиг в направлении доказательства гипотезы А. Сельберга ${ }^{165}$. Его идея - недиагональные члены оценивать, используя оценки тригонометрических сумм. В моей работе более искусно осуществляется эта идея, что и привело к усилению. Она помогла мне также разобраться в вопросах о нулях $\zeta(s)$.

3.9. "Метод тригонометрических сумм в теории чисел" (совместно с И. М. Виноградовым), Труды МИАН СССР, т. 168 (1984), с. 4-30. Обзорная статья. Предложил ее написать Е.Ф. Мищенко ${ }^{166}$. Я взял предыдущие сочинения И. М. на эту тему, объединил их, добавил последние достижения, прочитал И. М. (он был уже в Узком ${ }^{167}$ ). Получилась статья. Это последняя ${ }^{168}$ статья И. М.

160 Зенон Иванович Боревич.

${ }^{161}$ Игорь Ростиславович Шафаревич.

${ }^{162}$ См. [24].

${ }^{163}$ Аркадий Анатольевич Мальцев.

${ }^{164}$ См., например, статью: Г.И. Архипов, В.Н. Чубариков, "Об арифметических условиях разрешимости нелинейных систем диофантовых уравнений", Докл. АН СССР, 284:1 (1985), 16-21.

${ }^{165}$ Atle Selberg.

${ }^{166}$ Евгений Фролович Мищенко.

${ }^{167}$ Подмосковный санаторий, в котором заболевший И. М. Виноградов жил последние месяцы своей жизни.

${ }^{168}$ Иван Матвеевич Виноградов умер 20 марта 1983 г. 
3.10. "О нулях функции $\zeta(s)$ на коротких промежутках критической прямой”, Известия АН СССР. Серия математическая, т. 48, № 3 (1984), с. 569-584. Доказана гипотеза А. Сельберга, высказанная ${ }^{169}$ им в 1942 г. Основу доказательства составили соображения, о которых говорил в работе 3.8. Сначала думал, что нужны будут оценки сумм с простыми числами и квазириманова гипотеза. Потом понял, что ничего этого не надо и получил доказательство. Большое значение имело также то обстоятельство, что я упростил само доказательство А. Сельберга его теоремы; оно стало прямым и понятным (достаточно сравнить с тем, которое есть у Титчмарша в книге $\left.{ }^{170}\right)$.

3.11. “О нулях дзета-функции Римана", Доклады АН СССР, т. 276, № 3 (1984), c. 535-539. Короткое сообщение по работе 3.10 , хотя и по нему можно восстановить все доказательство.

3.12. “Квадратичные вычеты и невычеты в редких последовательностях", Доклады АН СССР, т. 279, № 5 (1984), с. 1044-1046. "Гибридные" теоремы, продолжающие мои работы $1.21,1.23,1.24,1.25,1.28 ; 2.2,2.9,2.11,2.12$. Тема - моя.

3.13. "Распределение нулей функции $\zeta(1 / 2+i t)$ ", Известия АН СССР. Серия математическая, т. 48, № 6 (1984), с. 1214-1224. Придумал задачу, которая является вариацией на тему гипотезы А. Сельберга: почти все короткие промежутки $\left(H=T^{\varepsilon}\right)$ имеют $\geqslant c H \ln T$ нулей $\zeta(1 / 2+i t)$, и решил ее. Хорошая задача.

Дальнейшим результатом (очень интересным) явилась (1986 г.) теорема Л. В. Киселевой ${ }^{171}$ подобного рода, но осреднение идет не по $(X, 2 X)$, а по $\left(X, X+X^{\theta}\right), \theta<1$ (у нее $\left.\theta=11 / 12\right)$. Тем самым, родилось целое новое направление: осреднять на коротких промежутках! (Надо посмотрть все задачи, которые связаны с подобной постановкой.)

3.14. “Метод тригонометрических сумм И.М. Виноградова", Труды МИАН CCCP, т. 163 (1984), с. 97-103. Изложение доклада, который я прочитал на конференции, посвященной 90-летию И. М. Пытался (и, по-моему, получилось) изложить идейную часть метода И. М. (двойные суммы, сглаживание). Потом нашел старые оттиски И. М. ( $\approx 1934$ г., 1935 г.), где он говорил то же самое (близко).

3.15. "О нулях функции $\zeta(1 / 2+i t)$ ", Доклады АН СССР, т. 281, № 5 (1985), c. 1038-1041. Короткое сообщение о результатах работы 3.13.

3.16. “О нулях функции $\zeta(s)$ в окрестности критической прямой”, Известия АН СССР. Серия математическая, т. 49, № 2 (1985), с. 326-333. Был осенью 1984 г. в Праге, в Карловом университете. Приехал ко мне Я. Мозер и говорит: "Вы доказали гипотезу Сельберга о нулях $\zeta(s)$ на критической прямой. Сельберг также ставил задачу о нулях в окрестности критической прямой. Ее надо сделать". Я попросил Б. Новака найти статью Сельберга. Он быстро сделал мне ксерокопию статьи, а на следующий день я уже написал статью с решением этой задачи. Конечно, после того, что я уже сделал (работы 3.10, 3.13), задача оказалась простой. Возможны дальнейшие развития этой темы в стиле работы 3.13.

3.17. “О вещественных нулях функции $\zeta(1 / 2+i t)$ ”, Успехи математических наук, т. 40, № 4(244) (1985), с. 171-172. Короткий обзор моих результатов по дзете.

3.18. “Дзета-функция Римана и ее нули”, Успехи математических наук, т. 40, № 5(245) (1985), с. 19-70. Большой обзор (с доказательствами, полными) моих результатов. Нет только работы 3.16. Большую помощь в скорейшей публикации оказал А. А. Мальцев.

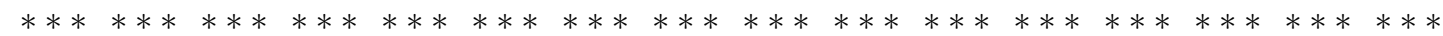

\footnotetext{
${ }^{169}$ См. статью: A. Selberg, "On the zeros of Riemann's zeta-function", Skr. Norske Vid. Akad. Oslo I, 10 (1942), $59 \mathrm{pp}$.

${ }^{170}$ Cм. [21].

171 Лариса Владимировна Киселева.
} 
3.19. “О функции $G(n)$ в проблеме Варинга”, Известия АН СССР. Серия математическая, т. 49, № 5 (1985), с. 935-947. По настоянию Г. И. Архипова написана статья. Дал $p$-адическое доказательство оценки $G(n)$. Оно не только идейно поясняет суть дела, но и дает лучший результат, чем у И. М. Я его знал давно. Это же будет в нашей книге.

Сейчас (1997 г.) Вон ${ }^{172}$ и Вули ${ }^{173}$ написали массу статей, пользуясь работой 3.19.

3.20. “О нулях дзета-функции Римана на критической прямой”, Труды МИАН CCCP, т. 167 (1985), с. 167-178. Полное изложение работы 3.8. Долго не выходило из печати (юбилейный сборник к 75 -летию Л. С. Понтрягина ${ }^{174}$ ). Все это было мной перекрыто (гипотеза Сельберга) в работе 3.10 и затем.

\section{Toм 4}

4.1. “Распределение простых чисел”, Успехи математических наук, т. 45, № 5 (275) (1990), с. 81-140. Изучал плотностные теоремы ${ }^{175}$ ( $\approx$ начало 1974 г.) Монтгомери, Хаксли ${ }^{176}$, Ютилы и других, придумал свое доказательство теоремы Хаксли. Долго не публиковал. Затем появился этот мой обзор, и основную его ценность представляет это доказательство. Замечу также, что здесь же помещено мое доказательство теоремы ${ }^{177}$ Римана-Мангольдта ${ }^{178}$ об $N(T)$. Такого доказательства я не встречал раньше.

4.2. “О нулях функции Дэвенпорта-Хейльбронна, лежащих на критической прямой", Известия АН СССР. Серия математическая, т. 54, № 2 (1990), с. 303-315. Писали с С. М. Ворониным книгу "Дзета-функция Римана"179. Поместили теорему Воронина о нулях $f(s)$. Доказательство очень сложное, и до конца его никто не разбирал. Стал думать о другом доказательстве. Думал, что высокая степень интеграла даст возможность лучше использовать осцилляцию, но все прикидки показывали, что надо брать малую степень $\alpha \rightarrow 0$. Условное доказательство (при условии, что могу снизу оценивать один интеграл) получил в июле-августе 1989 г. на поляне Москвина ${ }^{180}$ (Памир) и в селе Долинка ${ }^{181}$ (Тянь-Шань, Иссык-Куль). Поехал в октябре в Амальфи ${ }^{182}$, дискутировал с Э. Бомбьери (переводил А. Ивич), говорил, что понимаю, как сделать, но не могу пока оценить интеграл. Несколько раз переспрашивал Бомбьери, могут ли они (или он) доказать это, и он каждый раз отвечал, что нет, не могут, только думают, что это так (т.е. гипотеза). Приехал, открыл Титчмарша (дзету $\left.{ }^{183}\right)$, посмотрел неравенство Гэбриэла ${ }^{184}$ и сразу же получил доказательство своей теоремы.

\footnotetext{
${ }^{172}$ Robert Charles Vaughan.

${ }^{173}$ Trevor Wooley.

174 Лев Семенович Понтрягин.

175 См., например, [10; с. 103-104].

${ }^{176}$ Martin Neil Huxley.

${ }^{177}$ Пусть $N(T)$ - количество нулей $\zeta(s)$ в $0 \leqslant \operatorname{Re} s \leqslant 1,0<\operatorname{Im} s \leqslant T$. Тогда при $T \geqslant 2$ справедлива асимптотическая формула

$$
N(T)=\frac{T}{2 \pi} \log \frac{T}{2 \pi}-\frac{T}{2 \pi}-O(\log T) .
$$

${ }^{178}$ Georg Friedrich Bernhard Riemann. Hans Carl Friedrich von Mangoldt. См. статью: H. von Mangoldt, "Zur Verteilung der Nullstellen der Riemannschen Funktion $\xi(t)$ ", Math. Ann., 60 (1905), 1-19.

${ }^{179}$ CM. [9].

${ }^{180}$ Памирская поляна на высоте 4200 м., где находится базовый альпинистский лагерь для восхождений на расположенные поблизости высочайшие вершины Памира - пики Коммунизма (7495 м.) и Корженевской (7105 м.).

${ }^{181}$ Село на берегу озера Иссык-Куль в Киргизии в горах Тянь-Шаня недалеко от границы с Китаем, где А. А. Карацуба часто отдыхал с семьей.

${ }^{182}$ Курорт в Италии на побережье Тирренского моря южнее г. Сорренто, где в 1989 г. проводилась конференция по теории чисел, посвященная юбилею Энрико Бомбьери.

${ }^{183}$ CM. [21].

${ }^{184}$ Robert Mark Gabriel, см. статью: R. M. Gabriel, "Some results concerning integrals of moduli of regular functions along certain curves", J. London Math. Soc., 2 (1927), 111-117.
} 
Позднее уточнил результаты ${ }^{185}(\geqslant T \sqrt{\log T} \exp (-c \sqrt{\log \log T}))$, а также доказал этим методом теорему ${ }^{186}$ о нулях $\zeta(1 / 2+i t)$ на почти всех очень коротких промежутках.

\section{Список литературы}

[1] Теория чисел и анализ, Сборник статей. Труды Международной конференции по теории чисел, посвященной 100-летию со дня рождения академика И. М. Виноградова, Тр. МИАН, 207, ред. Е. Ф. Мищенко, А. А. Карацуба, Наука, М., 1994.

[2] Список научных публикаций, http://www.mi.ras.ru/ karatsuba/list.html.

[3] А. А. Карацуба, Основы аналитической теории чисел, Наука, М., 1975.

[4] A. A. Karatsuba, Fundamentos de la teoría analitica de los números, Mir, Moscow, 1979 (Spanish).

[5] Г. И. Архипов, А.А. Карацуба, В.Н. Чубариков, "Кратные тригонометрические суммы", Тр. МИАН СССР, 151, 1980, 3-128.

[6] А. А. Карацуба, Основы аналитической теории чисел, 2-е изд., Наука, М., 1983.

[7] Г. И. Архипов, А. А. Карацуба, В.Н. Чубариков, Теория кратных тригонометрических сумм, Наука, М., 1987.

[8] A. A. Karatsuba, Basic Analytic Number Theory, Springer-Verlag, Berlin, 1993.

[9] С. М. Воронин, А. А. Карацуба, Дзета-функиия Римана, Физматлит, М., 1994; А. А. Karatsuba, S. M. Voronin, The Riemann Zeta-Function, de Gruyter Exp. Math., 5, Walter de Gruyter, Berlin, 1992.

[10] A. A. Karatsuba, Complex Analysis in Number Theory, CRC Press, Boca Raton, FL, 1995.

[11] G. I. Arkhipov, V. N. Chubarikov, A. A. Karatsuba, Trigonometric Sums in Number Theory and Analysis, de Gruyter Exp. Math., 39, Walter de Gruyter, Berlin, 2004.

[12] Автоматы, Сборник статей, ред. К.Э. Шеннон, Дж. Маккарти, ИЛ, М., 1956.

[13] Loo-keng Hua, "On the number of solutions of Tarry's problem", Acta Sci. Sinica, 1 (1952), 1-76.

[14] И. М. Виноградов, "Новая оценка функции $(1+i t) "$, Изв. АН СССР. Сер. матем., 22:2 (1958), 161-164.

[15] A. Svoboda, M. Valach, "Operatorov e obvody (Operational circuits)", Stroje na Zpracování Informací, 3, Nakl. CSZV, Prague, 1955, 247-295.

[16] V. Strassen, "Gaussian elimination is not optimal", J. Numer. Math., 13:4 (1969), 354-356.

[17] Д. Кнут, Искусство программирования. Т. 2. Получисленные алгоритмы, Мир, М., 2000.

[18] А.Н. Колмогоров, Избранные труды. В 6 т. Т. 3. Теория иформации и теория алгоритмов, Наука, М., 1987.

[19] A. Schönhage, V. Strassen, "Schnelle Multiplikation großer Zahlen", Computing, 7:3-4 (1971), 281-292.

[20] А. А. Карацуба, "Приложение №4": Хуа Ло-кен, Метод тригонометрических сумм и его применения в теории чисел, Мир, М., 1964, 180-187.

[21] Е. К. Титчмарш, Теория дзета-функиии Римана, ИЛ, М., 1953.

[22] Г.И. Архипов, А.А. Карацуба, "О локальном представлении нуля формой", Изв. АН CCCP. Сер. матем., 45:5 (1981), 948-961.

[23] Г. И. Архипов, А. А. Карацуба, “Об одной задаче теории сравнений”, УМН, 37:5 (227) (1982), $161-162$.

[24] З. И. Боревич, И. Р. Шафаревич, Теория чисел, 3-е изд., доп., Наука, М., 1985.

\footnotetext{
${ }^{185}$ См. статью: А. А. Карацуба, "Уточнение теорем о количестве нулей, лежащих на отрезках критической прямой, некоторых рядов Дирихле", УМН, 47:2(284) (1992), 193-194.

${ }^{186}$ См. статью: А. А. Карацуба, “О количестве нулей дзета-функции Римана, лежащих на почти всех коротких промежутках критической прямой”, Изв. РАН. Сер. матем., 56:2 (1992), 372-397.
} 